\title{
Neuronal Nicotinic Acetylcholine Receptors Are Blocked by Intracellular Spermine in a Voltage-Dependent Manner
}

\author{
Ali Pejmun Haghighi and Ellis Cooper \\ Department of Physiology, McGill University, Montréal, Québec, Canada H3G 1 Y6
}

\begin{abstract}
A common feature of neuronal nicotinic acetylcholine receptors (nAChRs) is that they conduct inward current at negative membrane potentials but little outward current at positive membrane potentials, a property referred to as inward rectification. Physiologically, inward rectification serves important functions, and the main goal of our study was to investigate the mechanisms underlying the rectification of these receptors. We examined recombinant $\alpha_{3} \beta_{4}$ and $\alpha_{4} \beta_{2}$ neuronal nAChR subtypes expressed in Xenopus oocytes and native nAChRs expressed on superior cervical ganglion (SCG) neurons. Whole-cell AChevoked currents recorded from these receptors exhibited strong inward rectification. In contrast, we showed that singlechannel currents from these neuronal nAChRs measured in outside-out patches outwardly rectify. On the basis of recent findings that spermine, a ubiquitous intracellular polyamine, confers rectification to glutamate receptors and inwardly rectifying potassium channels, we investigated whether spermine
\end{abstract}

causes neuronal $\mathrm{nAChRs}$ to inwardly rectify. When spermine was added to the patch electrode in outside-out recordings, it caused a concentration- and voltage-dependent block of AChevoked single-channel currents. Using these single-channel data and physiological concentrations of intracellular spermine, we could account for the inward rectification of macroscopic whole-cell ACh-evoked conductance-voltage relationships. Therefore, we conclude that the voltage-dependent block by intracellular spermine underlies inward rectification of neuronal $\mathrm{nAChRs}$. We also found that extracellular spermine blocks both $\alpha_{3} \beta_{4}$ and $\alpha_{4} \beta_{2}$ receptors; this finding points to a mechanism whereby increases in extracellular spermine, perhaps during pathological conditions, could selectively block these receptors.

Key words: neuronal nAChRs; sympathetic neurons; inward rectification; single-channel currents; spermine; voltagedependent block; presynaptic modulation
Neuronal nicotinic acetylcholine receptors (nAChRs) are widespread in the nervous system where they function as postsynaptic receptors to excite neurons or as presynaptic receptors to modulate neurotransmitter release (Sargent, 1993; Role and Berg, 1996). Structurally, neuronal nAChRs are pentamers (Anand et al., 1991; Cooper et al., 1991); however, the precise subunit composition of functional nAChRs on a given neuron has not been fully resolved (McGehee and Role, 1995). In the peripheral nervous system (PNS), $\alpha_{3}$ and $\beta_{4}$ are the most abundant transcripts (Boyd et al., 1988; Couturier et al., 1990; Mandelzys et al., 1994), and most nAChRs are located postsynaptically at synapses formed between cholinergic preganglionic nerve terminals and postganglionic autonomic neurons. In the CNS, $\alpha_{4}$ and $\beta_{2}$ transcripts are the most abundant (Wada et al., 1989; Flores et al., 1992), and many nAChRs appear to be located on presynaptic nerve terminals (McGehee et al., 1995; McGehee and Role, 1996). The recent finding that a missense mutation in the $\alpha_{4}$ gene underlies autosomal dominant nocturnal frontal lobe epilepsy highlights the importance of neuronal nAChRs for normal CNS function (Steinlein et al., 1995; Weiland et al., 1996).

One striking feature common to all functional neuronal

Received Dec. 17, 1997; revised March 16, 1998; accepted March 17, 1998.

This work was supported by a grant from the Medical Research Council of Canada to E.C. A.P.H. was supported by a doctoral fellowship from the Natural Sciences and Engineering Research Council of Canada. We thank Drs. J. Hanrahan,

P. Linsdell, and P. Drapeau and also members of the Cooper lab for their helpful suggestions and critical comments on this manuscript.

Correspondence should be addressed to Dr. Ellis Cooper, Department of Physiology, McIntyre Medical Building, Room 1127, 3655 Drummond Street, Montréal, Québec, H3G 1Y6, Canada.

Copyright (ㄷ) 1998 Society for Neuroscience $\quad 0270-6474 / 98 / 184050-13 \$ 05.00 / 0$
nAChRs, regardless of whether they are expressed on neurons or heterologously in non-neuronal cells, is the strong inward rectification that results from a progressive reduction in channel conductance as the membrane potential depolarizes over the physiological range (Bertrand et al., 1990; Mathie et al., 1990; Ifune and Steinbach, 1991, 1992; Sands and Barish, 1992). Physiologically, this inward rectification serves important functions. For presynaptic receptors, inward rectification ensures that the receptors will not depress transmitter release by decreasing the input resistance of the terminal. For postsynaptic receptors, fluctuations in membrane potential near rest change the conductance of the receptors and consequently affect synaptic effectiveness. The factors that cause neuronal nAChRs to rectify have not been fully characterized. If rectification is not constant, then changes in rectification can alter synaptic efficacy.

Previous studies suggest that both intrinsic channel properties and block by intracellular $\mathrm{Mg}^{2+}$ contribute to inward rectification of neuronal nAChR channels (Mathie et al., 1990; If une and Steinbach, 1991; Sands and Barish, 1992). However, these factors only partially account for the rectification, suggesting that unidentified factors are involved (Ifune and Steinbach, 1993; Forester and Bertrand, 1995). Interestingly, inward rectification of wholecell ACh-evoked currents in rat phaeochromocytoma (PC12) cells was reduced when cells were extensively dialyzed with $\mathrm{Na}_{2}$ ATP (Sands and Barish, 1992; If une and Steinbach, 1993). ATP is known to effectively chelate spermine, a ubiquitous polyamine (Watanabe et al., 1991). Therefore, it is conceivable that intracellular free spermine contributes to the inward rectification of neuronal nAChRs, as demonstrated for inward rectifier potassium channels and glutamate receptors (Ficker et al., 1994; Bowie 
and Mayer, 1995; Fakler et al., 1995). The objective of our study was to examine whether intracellular spermine produces inward rectification of neuronal nAChRs. We studied $\alpha_{4} \beta_{2}$ and $\alpha_{3} \beta_{4}$ receptors expressed in Xenopus oocytes, as well as native $\mathrm{nAChRs}$ expressed on rat superior cervical ganglion (SCG) neurons. Our results suggest that inward rectification of neuronal nAChRs can result from a voltage-dependent block by intracellular spermine.

Parts of these results have been reported in abstract form (Haghighi and Cooper, 1997).

\section{MATERIALS AND METHODS}

\section{Preparation of SCG neurons}

SCG ganglia were dissected from postnatal day 18-26 Sprague Dawley rats (Charles River) and dissociated mechanically and enzymatically as described previously (McFarlane and Cooper, 1992). Briefly, the ganglia were dissected under sterile conditions from animals killed by cervical dislocation. The ganglia were dissociated at $37^{\circ} \mathrm{C}$ either in collagenase $(1$ $\mathrm{mg} / \mathrm{ml}$, type I; Sigma, St. Louis, MO) for $15 \mathrm{~min}$ followed by dispase (2.4 $\mathrm{mg} / \mathrm{ml}$, grade II; Boehringer Mannheim, Indianapolis, IN) for 30-45 $\mathrm{min}$ or in an enzyme mixture containing trypsin $(1 \mathrm{mg} / \mathrm{ml}$; Sigma), deoxyribonuclease $(5 \mu \mathrm{g} / \mathrm{ml}$; Sigma $)$ and bovine serum albumin $(6 \mathrm{mg} /$ $\mathrm{ml}$; Sigma) (Mathie et al., 1990) for $45 \mathrm{~min}$. All enzymes were dissolved in HBSS (without $\mathrm{Ca}^{2+}$ or $\mathrm{Mg}^{2+}$ ). The ganglia were gently triturated after the enzyme treatment using a fire-polished Pasteur pipette until they were completely dissociated. Dissociated neurons were washed with L-15 medium supplemented with $10 \%$ horse serum and plated onto laminin-coated $\left(40 \mathrm{gm} / \mathrm{ml}\right.$; overnight at $4^{\circ} \mathrm{C}$; gift of Dr. S. Carbonetto, McGill University) Aclar coverslips (Allied Chemicals, Clifton, NJ) in modified Petri dishes. The neurons were incubated in $1.5 \mathrm{ml}$ of L-15 medium supplemented with $5 \%$ rat serum, vitamins, cofactors, penicillin, streptomycin, and sodium bicarbonate as described previously (Hawrot and Patterson, 1979). The media was also supplemented with nerve growth factor (2.5S NGF, $25 \mathrm{ng} / \mathrm{ml}$; gift of Dr. S. Carbonetto). The cultures were maintained at $37^{\circ} \mathrm{C}$ in a humidified incubator with an atmosphere of $5 \% \mathrm{CO}_{2}$ and $95 \%$ air. Neurons were used for electrophysiology within $48 \mathrm{hr}$ (often within $24 \mathrm{hr}$ ) after plating.

\section{Preparation and nuclear injection of oocytes}

Xenopus oocytes were defolliculated and prepared as described by Bertrand et al. (1991). We injected 1-3 ng of pairwise combinations of cDNAs coding for neuronal nAChR subunits $\alpha_{4}$ and $\beta_{2}, \alpha_{4}$ and $\beta_{2}$ E260, or $\alpha_{3}$ and $\beta_{4}$ into the nucleus of oocytes. In $\beta_{2}$ E260, the lysine (K) residue at the position 260 (part of the extracellular ring of charged residues) has been substituted with an glutamic acid residue (E), which increases the single-channel conductance (Cooper et al., 1991). Rat $\alpha_{3}$ and $\beta_{4}$ cDNAs were cloned into the pCDNA1 expression vector (Invitrogen, San Diego, $\mathrm{CA}$ ), and chick $\alpha_{4}, \beta_{2}$, and $\beta_{2} \mathrm{E} 260$ were cloned into derivatives of pSV2.cat expression vectors (Bertrand et al., 1991). Oocytes were incubated at $19^{\circ} \mathrm{C}$ for $48-72 \mathrm{hr}$ before recording. For single-channel experiments, the vitelline membrane surrounding the oocytes was removed.

\section{Electrophysiology}

Whole-cell recordings from oocytes. To measure the macroscopic AChevoked currents in oocytes, we used two-electrode voltage-clamp techniques (Bertrand et al., 1991). These experiments were performed at room temperature $\left(22-24^{\circ} \mathrm{C}\right)$ using a standard voltage-clamp amplifier (built by Mr. A. Sherman, McGill University). During the recordings, oocytes were perfused with control perfusion solution or agonist solutions at $10-20 \mathrm{ml} / \mathrm{min}$; the switch from one solution to another was performed manually. Currents were sampled at $100-350 \mathrm{~Hz}$ on-line with a 386-based PC computer (AT class running at $33 \mathrm{MHz}$ and a $64 \mathrm{~K}$ cache and A/D card; Omega, Stamford, CT). The program PATCHKIT (Alembic Software, Montréal) was used for stimulation and data acquisition. Recording electrodes had tip diameters of $10-15 \mu \mathrm{m}$ and were filled with $3 \mathrm{~m} \mathrm{KCl}$. Only oocytes that gave rise to large inward currents $\left(>1 \mu \mathrm{A}\right.$ in response to $1 \mu \mathrm{M}$ ACh for $\alpha_{4} \beta_{2}$-expressing oocytes or $10 \mu \mathrm{M}$ ACh for $\alpha_{3} \beta_{4}$-expressing oocytes when voltage-clamped at $-60 \mathrm{mV}$ ) were used for single-channel recordings. External perfusing solution contained $96 \mathrm{~mm} \mathrm{NaCl}, 2 \mathrm{~mm} \mathrm{KCl}, 1 \mathrm{~mm} \mathrm{NaH} \mathrm{PO}_{4}, 1 \mathrm{~mm} \mathrm{BaCl}{ }_{2}, 10 \mathrm{~mm}$ HEPES, and $1 \mu \mathrm{M}$ atropine; $\mathrm{pH}$ was adjusted with $\mathrm{NaOH}$ to 7.4-7.5.
Spermine (Sigma) was dissolved in sterile water, and aliquots were kept frozen at $-20^{\circ} \mathrm{C}$.

Single-channel recordings from oocytes. Outside-out recordings were performed using a List EPC-7 amplifier at room temperature $\left(22-24^{\circ} \mathrm{C}\right)$ (Hamill et al., 1981). Pipette resistance ranged from 5 to $10 \mathrm{M} \Omega$ for outside-out recordings, and electrodes were coated with Sylgard (Dow Corning, Corning, NY). Recordings were obtained in the continuous presence of ACh $(0.1-0.2 \mu \mathrm{M})$ in the recording bath. ACh-evoked single-channel activity gradually diminished in $2-5$ min after excision of the patch. Signals were digitized with a PCM (501, Sony, Tokyo, Japan) and stored on VCR tapes. For off-line analysis, the stored signals were first filtered at $1.5-2 \mathrm{kHz}$ with an eight-pole Bessel filter (Frequency Devices) and sampled at $10-20 \mathrm{kHz}$ using a 386 -based PC computer. The program PATCHKIT was used for stimulation and data acquisition. External solution contained $100 \mathrm{~mm} \mathrm{KCl}, 1 \mathrm{~mm} \mathrm{CaCl}_{2}, 10 \mathrm{HEPES}$, and $1 \mu \mathrm{M}$ atropine, and $\mathrm{pH}$ was adjusted to 7.4 with $\mathrm{KOH}$. Recording electrodes contained $80 \mathrm{~mm} \mathrm{KF}, 20 \mathrm{~mm}$ potassium acetate, $10 \mathrm{~mm}$ HEPES, and $10 \mathrm{~mm}$ EGTA; pH was adjusted to 7.4 with KOH.

Whole-cell recordings from SCG neurons. Whole-cell patch-clamp recordings on SCG neurons were performed at room temperature (22$24^{\circ} \mathrm{C}$ ) using a List EPC-7 amplifier (Hamill et al., 1981). Throughout the recordings neurons were perfused with the external solution at a rate of $1 \mathrm{ml} / \mathrm{min}$, and agonists were applied by pressure ejection from pipettes with tip diameters of 20-30 $\mu \mathrm{m}$ (Mandelzys et al., 1995). Currents were filtered at $1.5 \mathrm{kHz}$ with an eight-pole Bessel filter (Frequency Devices), sampled at $2.5-5 \mathrm{kHz}$, and displayed and stored on-line with a 386-based PC computer. The program PATCHKIT was used for stimulation and data acquisition. The resistance of patch pipettes ranged from 2 to $6 \mathrm{M} \Omega$, and $50-60 \%$ of the series resistance was compensated. External perfusing solution contained $140 \mathrm{~mm} \mathrm{NaCl}, 5.4 \mathrm{mM} \mathrm{KCl}, 0.33 \mathrm{mM} \mathrm{NaH}_{2} \mathrm{PO}_{4}$, $0.44 \mathrm{~mm} \mathrm{KH}_{2} \mathrm{PO}_{4}, 2.8 \mathrm{~mm} \mathrm{CaCl}_{2}, 10 \mathrm{~mm}$ HEPES, $5.6 \mathrm{~mm}$ glucose, $2 \mathrm{~mm}$ glutamine, $0.5-1 \mu \mathrm{M}$ TTX (Sigma), and $1 \mu \mathrm{M}$ atropine; $\mathrm{pH}$ was adjusted to 7.4. ACh (acetylcholine iodide; Sigma) was dissolved in the same external perfusing solution $(100 \mu \mathrm{M})$. Recording electrodes were filled with intracellular solution containing $70 \mathrm{~mm} \mathrm{KF}, 65 \mathrm{~mm}$ potassium acetate, $5 \mathrm{~mm} \mathrm{NaCl}, 1 \mathrm{~mm} \mathrm{MgCl}_{2}, 10 \mathrm{~mm}$ EGTA, and $10 \mathrm{~mm}$ HEPES; $\mathrm{pH}$ was adjusted to 7.4 with $\mathrm{KOH}$.

Single-channel recordings from SCG neurons. Outside-out recordings were performed on SCG neurons as described above for oocytes. Agonists were applied by a manual switch through a micropipette, and neurons were washed with control solutions between each recording. Recording electrodes were fire-polished after they were coated with Sylgard. SCG outside-out patches also showed a rapid rundown of singlechannel activity (2-4 min) in all cases. External solution was identical to that described for whole-cell experiments except that the ACh concentrations were 5-20 $\mu \mathrm{M}$. Recording electrodes contained $70 \mathrm{~mm}$ Csgluconate, $70 \mathrm{~mm} \mathrm{CsF}, 1 \mathrm{~mm} \mathrm{MgCl}_{2}, 10 \mathrm{~mm}$ HEPES, and 10 EGTA; $\mathrm{pH}$ was adjusted to 7.4 with $\mathrm{CsOH}$.

Voltage-clamp protocols. For $I-V$ curves we measured ACh-evoked currents either by holding the membrane potentials $\left(V_{\mathrm{m}}\right)$ at different levels or in response to voltage ramps. Voltage-ramp protocols were as follows: whole-cell oocytes, $333 \mathrm{mV} / \mathrm{sec}$; whole-cell neurons, 333 or 200 $\mathrm{mV} / \mathrm{sec}$; outside-out recordings, $1 \mathrm{~V} / \mathrm{sec}, 333 \mathrm{mV} / \mathrm{sec}$, or $200 \mathrm{mV} / \mathrm{sec}$. We also used voltage-step protocols in which we stepped the holding potential rapidly between 40,50 , and $60 \mathrm{mV}$ and held at each potential for $1 \mathrm{sec}$.

\section{Analysis}

Whole-cell and single-channel ramp $I-V$ curves were obtained by subtracting the current in the absence of agonist from that in the presence of agonist. All $I-V$ curves were fit by eye to a polynomial function using Origin 4.1 graphics software (MICROCAL Software). To measure the amplitude of single-channel currents, we used either all-points histograms of open and closed distributions, or we measured the amplitude of the channel openings individually using PATCHKIT and then plotted values ( $>50$ openings) on a histogram. Histograms were fit by gaussian curves using Origin 4.1 graphics software. Some outside-out patches, especially from SCG neurons, gave rise to a nonspecific steady-state conductance at potentials above $+20 \mathrm{mV}$, which made the clear detection of ACh-evoked single-channel openings difficult.

To measure the relative open-channel probability $\left(p_{\text {open }}\right)$, we used single-channel recordings in response to $1 \mathrm{sec}$ voltage steps between \pm 40 , \pm 50 , and $\pm 60 \mathrm{mV}$. At each $V_{\mathrm{m}}$, we integrated the area under the all-points amplitude histograms corresponding to closed and open 
states of the receptors and then divided the area of the open state by the total area. Then we calculated the relative $p_{\text {open }}$ for $\pm 40, \pm 50$, and $\pm 60 \mathrm{mV}$ by dividing the $p_{\text {open }}$ at the positive $V_{\mathrm{m}}$ by that at the corresponding negative $V_{\mathrm{m}}$. The conductance $(G)$ was determined from $G=I /\left(V_{\mathrm{m}}-E_{\mathrm{rev}}\right)$.

We used a derivation of the Woodhull (1973) equation (see Results) to fit the $G-V$ relationships. All fits were performed using Origin 4.1 based on a Levenberg-Marquardt algorithm, and the best fit was achieved by $\chi^{2}$ minimization. Statistical significance was examined using ANOVA.

\section{RESULTS}

\section{Inward rectification of macroscopic ACh currents}

ACh-evoked currents through nicotinic receptors on neurons are carried by small monovalent and divalent cations. A property common to all functional neuronal nicotinic receptors is that they conduct inward current when the membrane potential $\left(V_{\mathrm{m}}\right)$ is negative, but pass little outward current when $V_{\mathrm{m}}$ is positive. To observe the rectification on neonatal rat SCG neurons, we applied voltage ramps to change $V_{\mathrm{m}}$ from $-60 \mathrm{mV}$ to $+50 \mathrm{mV}$ at a rate of $333 \mathrm{mV} / \mathrm{sec}$ before and during ACh application (Fig. $1 A$ ). We obtained the current-voltage $(I-V)$ curve by subtracting the control current from the current during the ACh application (Fig. $1 B)$. The small amount of desensitization of the ACh-evoked current had minimal effect on the shape of the $I-V$ curve. The ratio of the whole-cell ACh-evoked current at $+50 \mathrm{mV}$ to that at $-60 \mathrm{mV}$ is $0.01 \pm 0.008(n=10)$. Similar rectification is observed when $V_{\mathrm{m}}$ is held steady at different potentials during $\mathrm{ACh}$ application (data not shown). Comparable inward rectification has been reported previously for ACh-evoked currents in adult rat sympathetic neurons (Mathie et al., 1990, 1991), rat adrenal chromaffin cells (Hirano et al., 1987), and rat PC12 cells (Neuhaus and Cachelin, 1990; If une and Steinbach, 1992; Sands and Barish, 1992).

Recombinantly expressed neuronal nAChRs also exhibit strong inward rectification. Figure $2 A, B$ shows an example of an AChevoked $I-V$ curve and the corresponding chord conductancevoltage $(G-V)$ curve for $\alpha_{3} \beta_{4}$ receptors expressed in Xenopus oocytes. Figure $2 C, D$ shows an example of an ACh-evoked $I-V$ curve and the $G-V$ curve for $\alpha_{4} \beta_{2}$ receptors expressed in Xenopus oocytes. These figures demonstrate that both $\alpha_{4} \beta_{2}$ and $\alpha_{3} \beta_{4}$ receptors show strong inward rectification, and the conductance of these receptors progressively decreases as $V_{\mathrm{m}}$ depolarizes from $-80 \mathrm{mV}$. We have also investigated a mutant $\alpha_{4} \beta_{2}$ receptor in which the lysine at position 260 on the $\beta_{2}$ subunit has been changed to a glutamic acid; this mutation increases the singlechannel conductance of the $\alpha_{4} \beta_{2}$ receptors (Cooper et al., 1991) (Fig. 3), and we refer to it as $\alpha_{4} \beta_{2}$ E260. Our reason for using this mutant receptor is that alteration of charged residues at the extracellular mouth of the pore has been shown to influence rectification of muscle nAChRs (Imoto et al., 1988). Figure $2 E$ shows an example of an $I-V$ curve for $\alpha_{4} \beta_{2}$ E260 receptors expressed in Xenopus oocytes. Qualitatively, $\alpha_{4} \beta_{2}$ E260 receptors rectify in a manner similar to wild-type $\alpha_{4} \beta_{2}$ receptors. Similarly, the $G-V$ plot in Figure $2 F$ demonstrates that the conductance of $\alpha_{4} \beta_{2}$ E260 receptors decreases progressively as $V_{\mathrm{m}}$ depolarizes. At very positive potentials $(>60 \mathrm{mV})$, all three receptors conduct some outward current (data not shown). The $V_{1 / 2}$ values obtained from the $G-V$ curves are not significantly different for $\alpha_{3} \beta_{4}, \alpha_{4} \beta_{2}$, and $\alpha_{4} \beta_{2}$ E260 subtypes and for native nAChRs on SCG neurons; this suggests that their inward rectification properties are similar.
A
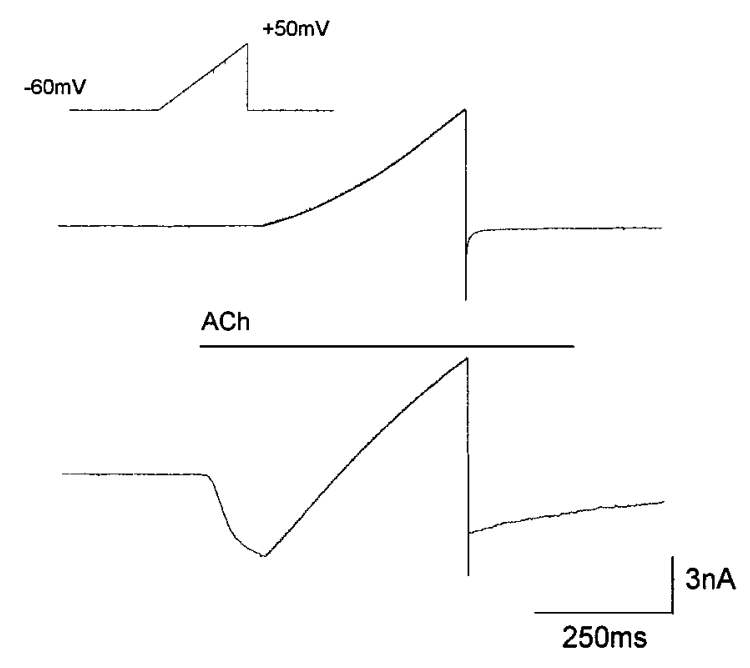

B

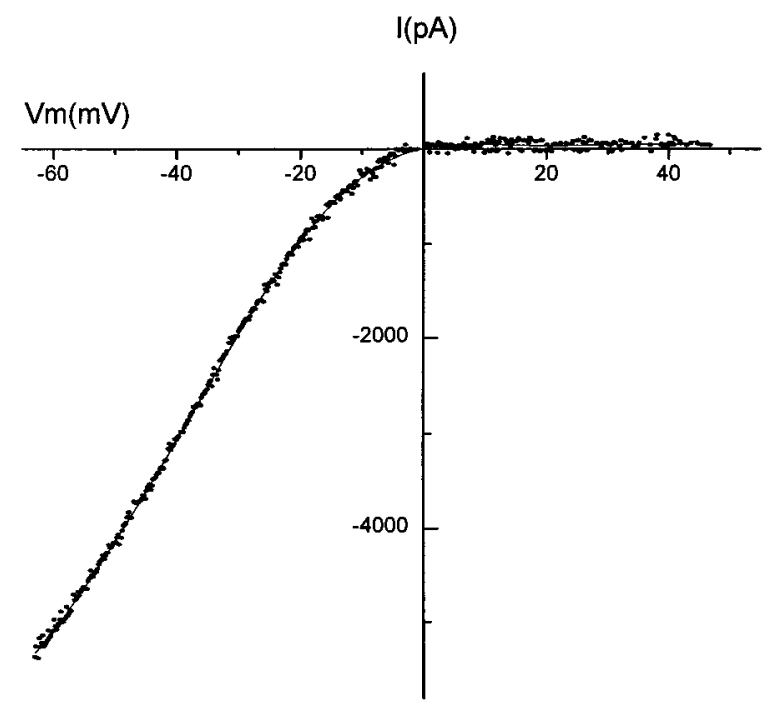

Figure 1. Macroscopic ACh-evoked currents recorded from SCG neurons show strong inward rectification. $A$, Whole-cell currents were recorded from an SCG neuron while the membrane potential was ramped from -60 to $+50 \mathrm{mV}(333 \mathrm{mV} / \mathrm{sec})$. The top trace shows the response of the neuron in the absence of agonist, and the bottom trace shows the response to $100 \mu \mathrm{M} \mathrm{ACh}$. $B$, This figure shows the current-voltage $(I-V)$ relationship for the neuron in $A$. The whole-cell $I-V$ curve was obtained by subtracting the current in control solution from the current in the presence of $\mathrm{ACh}$, during the voltage ramp. The $I-V$ plot shows strong inward rectification.

\section{Lack of inward rectification in single $\mathrm{nAChRs}$ measured from outside-out patches of Xenopus oocytes}

In contrast to what we observed at the macroscopic level, single nAChRs measured in outside-out patches conducted current in both directions equally well through the receptor. Figure 3 shows examples of single-channel currents from $\alpha_{3} \beta_{4}, \alpha_{4} \beta_{2}$, and $\alpha_{4} \beta_{2}$ E260 receptors recorded from outside-out patches held at four different potentials (Fig. $3 A, C, E$ ) and the corresponding single-channel $I-V$ curves (Fig. $3 B, D, F$ ). These records were 
A $\alpha_{3} \beta_{4}$
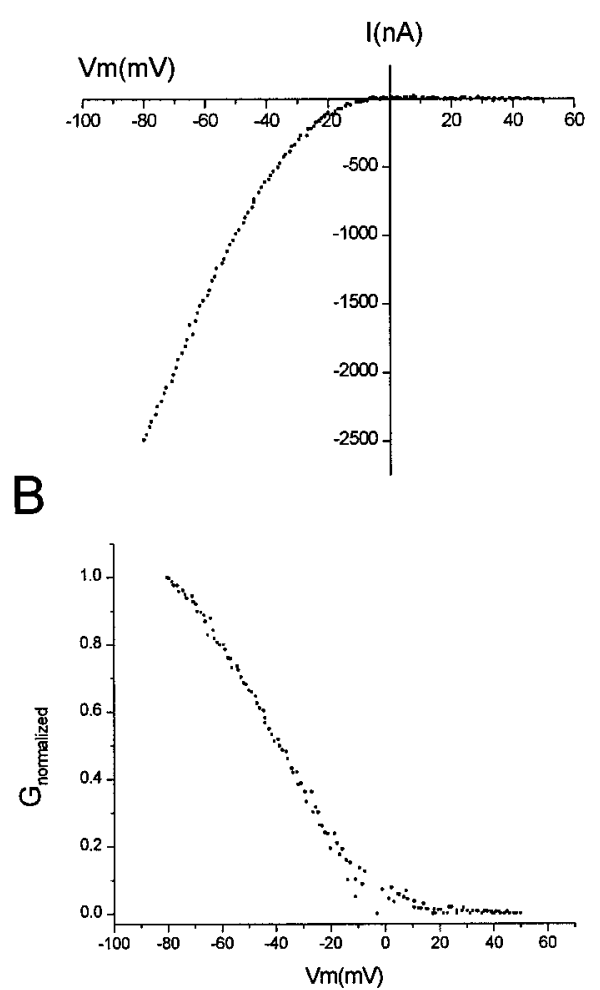

$\mathrm{C} \alpha_{4} \beta_{2}$
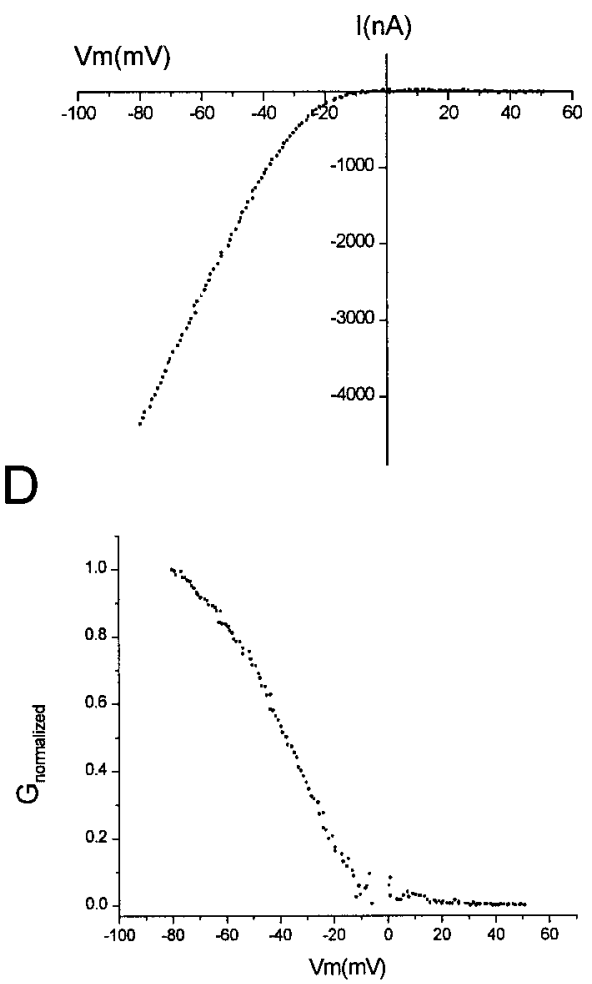

$\mathrm{E} \alpha_{4} \beta_{2} \mathrm{E} 260$
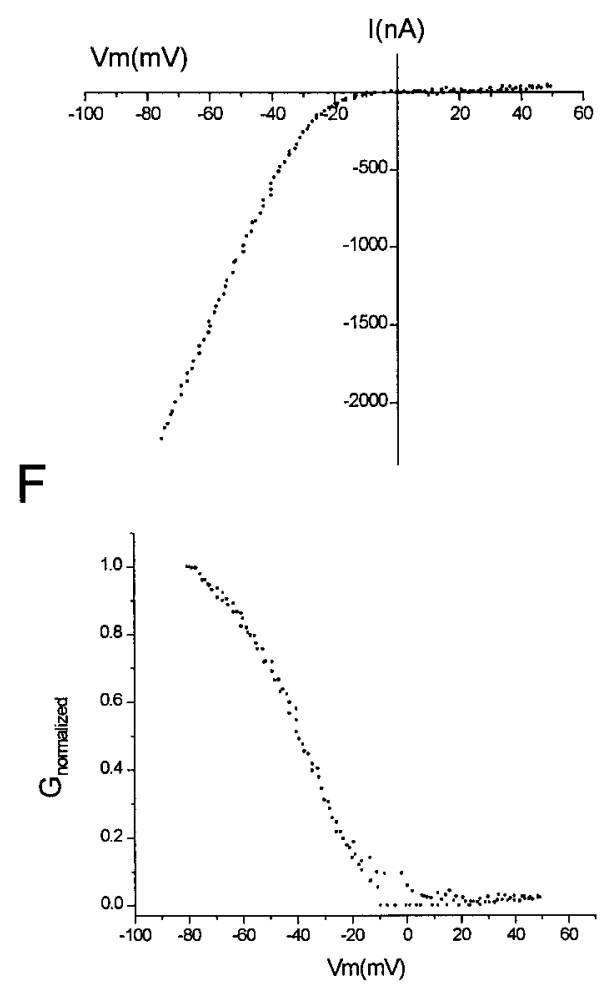

Figure 2. Whole-cell ACh-evoked current-voltage relationships for recombinant $\alpha_{3} \beta_{4}, \alpha_{4} \beta_{2}$, and $\alpha_{4} \beta_{2}$ E260 expressed in Xenopus oocytes show strong inward rectification. $A, C$, and $E$ show whole-cell $I-V$ curves for three oocytes expressing recombinant $\alpha_{3} \beta_{4}, \alpha_{4} \beta_{2}$, and $\alpha_{4} \beta_{2} \mathrm{E} 260$, respectively. Macroscopic currents were recorded in response to voltage ramps from -80 to $+50 \mathrm{mV}(333 \mathrm{mV} / \mathrm{sec})$ in the absence or presence of ACh $\left(1 \mu \mathrm{M}\right.$ for $\alpha_{4} \beta_{2}$ and $\alpha_{4} \beta_{2} \mathrm{E} 260$, and $20 \mu \mathrm{M}$ for $\alpha_{3} \beta_{4}$ ), and the net currents were obtained as explained in Figure 1. Note: the strong inward rectification of the $I-V$ curve is similar to that of whole-cell $I-V$ in SCG neurons (Fig. $1 B) . B, D$, and $F$ show the corresponding conductance-voltage relationships $\left(G-V\right.$ plot) for $\alpha_{3} \beta_{4}$, $\alpha_{4} \beta_{2}$, and $\alpha_{4} \beta_{2} E 260$, respectively. Conductance at each holding potential is normalized to the conductance at $-80 \mathrm{mV}$.

obtained in symmetrical $\mathrm{K}^{+}$concentrations $(100 \mathrm{~mm})$, with $\mathrm{K}^{+}$ being the main charge carrier. Under these conditions, $\alpha_{3} \beta_{4}$ receptors (Fig. $3 A$ ) have a single-channel conductance of $45 \pm$ $0.87 \mathrm{pS}$ (mean $\pm \mathrm{SE}$, at $-100 \mathrm{mV}$ ) and rectify slightly outward $[(I @+60 \mathrm{mV}) /(I @-60 \mathrm{mV})=1.2 \pm 0.13]$. Similarly, both $\alpha_{4} \beta_{2}$ and $\alpha_{4} \beta_{2}$ E260 receptors in outside-out patches conducted current in both directions (Fig. 3C,E). The single-channel conductance for $\alpha_{4} \beta_{2}$ receptors recorded in symmetrical $\mathrm{K}^{+}$was $49 \pm 0.68 \mathrm{pS}$ and that for $\alpha_{4} \beta_{2} \mathrm{E} 260$ was $61 \pm 0.81 \mathrm{pS}$. All three receptors showed a smaller single-channel conductance when extracellular $\mathrm{K}^{+}$was substituted with $\mathrm{Na}^{+}$(Cooper et al., 1991) or Cs ${ }^{+}$(data not shown). The $I-V$ curve for $\alpha_{4} \beta_{2}$ E260 receptors shows less outward rectification than those for $\alpha_{3} \beta_{4}$ and $\alpha_{4} \beta_{2}$ receptors as a result of introducing of negative charges to the extracellular ring of the pore (Imoto et al., 1988).

The results in Figure 3 indicate that inward rectification of macroscopic ACh-evoked currents is not because neuronal nACh receptors cannot pass outward currents. Similar results have been reported for nAChRs on adult rat sympathetic neurons (Mathie et al., 1990, 1991), rat adrenal chromaffin cells (Hirano et al., 1987), and rat PC12 cells (Neuhaus and Cachelin, 1990; If une and Steinbach, 1991, 1992; Sands and Barish, 1992).

We investigated whether the rectification of macroscopic AChevoked currents occurs because these receptors have a decreased open channel probability ( $\left.p_{\text {open }}\right)$ at depolarized potentials. For these experiments, we recorded single-channel currents from $\alpha_{4} \beta_{2}$ and $\alpha_{4} \beta_{2}$ E260 receptors in outside-out patches while repeatedly stepping $V_{\mathrm{m}}$ between $\pm 40, \pm 50$ (Fig. $4 A$ ), and $\pm 60 \mathrm{mV}$. The results indicate that there is a $25-30 \%$ reduction in $p_{\text {open }}$ at +40 , +50 , and +60 potentials compared with $p_{\text {open }}$ at the corresponding negative potentials: $p_{\text {open }(+40)} / p_{\text {open }(-40)}=0.72 \pm 0.3$; $p_{\text {open }(+50)} / p_{\text {open }(-50)}=0.75 \pm 0.2 ; p_{\text {open }(+60)} / p_{\text {open }(-60)}=0.71 \pm$ 0.4 ( $n=3$ patches, $10-20$ steps per patch). This reduction of $p_{\text {open }}$ at depolarized potentials, however, is too small to account for the inward rectification observed at the whole-cell level.

In a few experiments, we also measured ACh-evoked currents from macropatches in outside-out configuration while ramping the membrane potential (Fig. 4B). Consistent with what we observed for $p_{\text {open }}$ in the experiments above, the ACh-evoked currents from these macropatches exhibited only a small degree of rectification.

To test whether fast changes in the membrane potential can affect the opening of the receptors, we recorded ACh-evoked single channels from outside-out patches while rapidly ramping the patch holding potential from -100 to $+90 \mathrm{mV}$. Figure $4 C$ shows two superimposed $\alpha_{4} \beta_{2}$ single-channel records measured under these conditions. These records illustrate opening of singlechannel $\alpha_{4} \beta_{2}$ receptors while the membrane potential is rapidly 


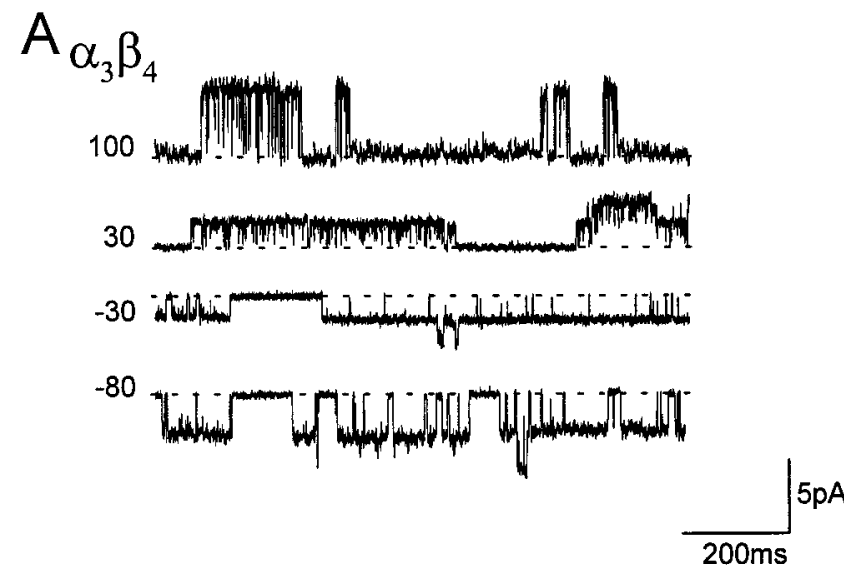

$\mathrm{C}_{\alpha_{4} \beta_{2}}$

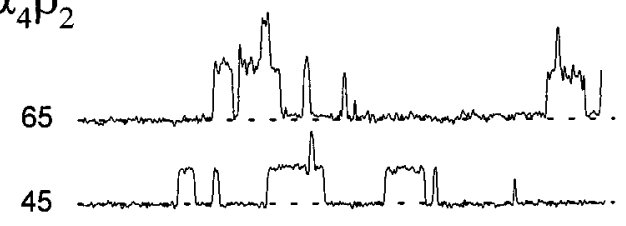

$-45$

$-70$

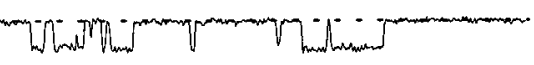

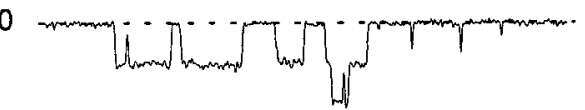

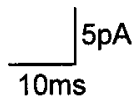

E

$\alpha_{4} \beta_{2} E 260$

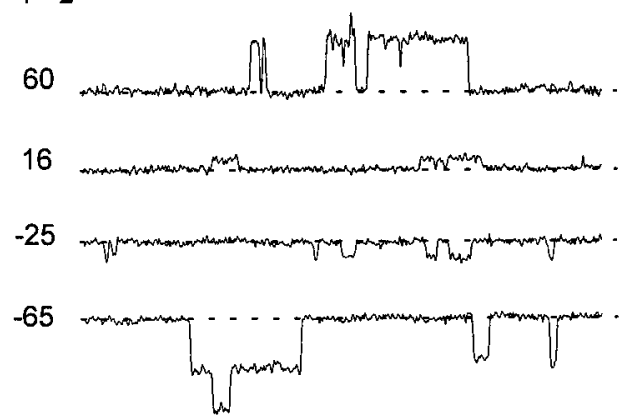

$\prod_{10 \mathrm{~ms}} 5 \mathrm{pA}$
B

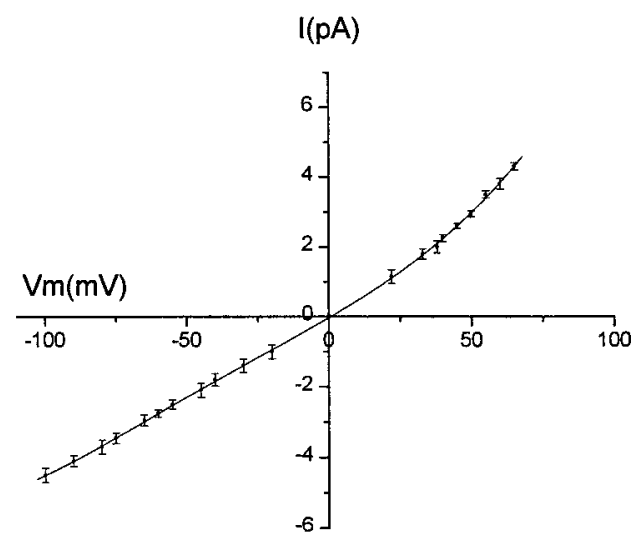

D

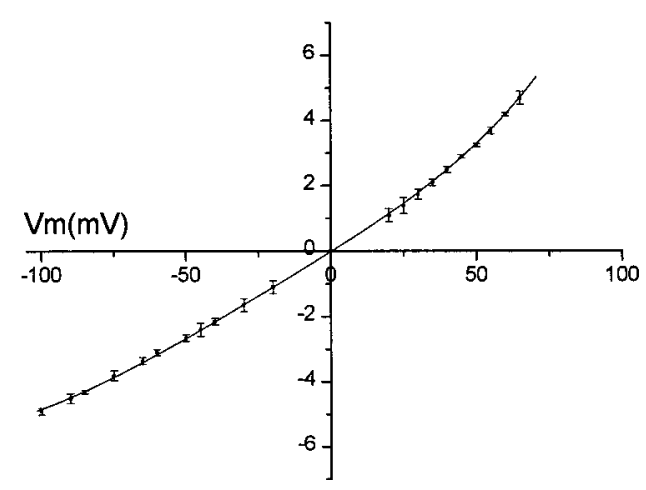

$F$

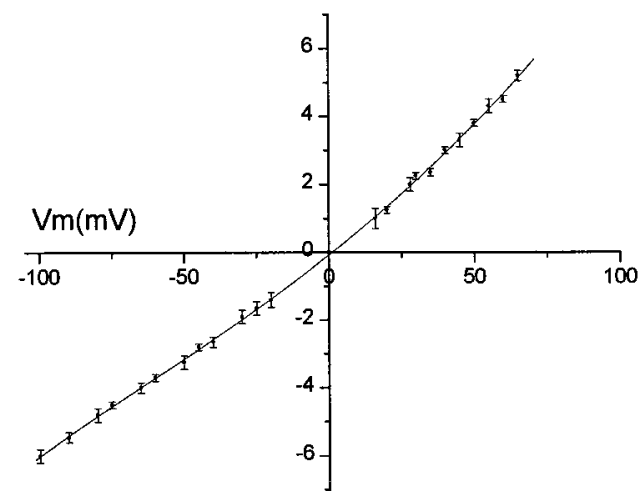

Figure 3. Outside-out single-channel currents from Xenopus oocytes expressing $\alpha_{3} \beta_{4}, \alpha_{4} \beta_{2}$, and $\alpha_{4} \beta_{2} \mathrm{E} 260$ do not show inward rectification. $A$, $C$, and $E$ show steady-state single-channel recordings from outside-out patches of oocytes expressing $\alpha_{3} \beta_{4}, \alpha_{4} \beta_{2}$, or $\alpha_{4} \beta_{2}$ E260, respectively. These recordings were performed in the continuous presence of ACh: 100-200 nM for $\alpha_{4} \beta_{2}$ and $\alpha_{4} \beta_{2} \mathrm{E} 260$ and 1-2 $\mu \mathrm{M}$ for $\alpha_{3} \beta_{4}$. Numbers on the left of each trace correspond to the holding potential at which that recording was obtained. The dotted lines mark the zero current level for each trace. $B, D$, and $F$ show the single-channel $I-V$ plots for $\alpha_{3} \beta_{4}, \alpha_{4} \beta_{2}$, or $\alpha_{4} \beta_{2} \mathrm{E} 260$, respectively. These $I-V$ plots, in contrast to the corresponding macroscopic $I-V$ plots (Fig. $2 A, C, E$ ), show a slight outward rectification. Each point in the plots represents the mean $\pm \mathrm{SE}$ of single-channel current amplitudes from four patches for $\alpha_{3} \beta_{4}$, eight patches for $\alpha_{4} \beta_{2}$, and eight patches for $\alpha_{4} \beta_{2} \mathrm{E} 260$.

changed from -100 to $+90 \mathrm{mV}$ at $1 \mathrm{~V} / \mathrm{sec}$. The average frequency of opening at positive potentials was $20-25 \%$ less than that at negative potentials.

The results of these cell-free single-channel experiments suggest that inward rectification of the ACh-evoked current is caused by an intracellular(s) mediator. It had been suggested that intracellular $\mathrm{Mg}^{2+}$ could cause a moderate rectification at single- channel level through a voltage-dependent blocking mechanism (Mathie et al., 1990; If une and Steinbach, 1991). However, extensive chelation of intracellular $\mathrm{Mg}^{2+}$ had very little effect on the rectification properties of the whole-cell currents (Mathie et al., 1990; Neuhaus and Cachelin, 1990). We found that including $\mathrm{Mg}^{2+}$ (up to $1 \mathrm{~mm}$ ) in the pipette solution in outside-out recordings had little effect on either the single-channel $I-V$ curves for 
A

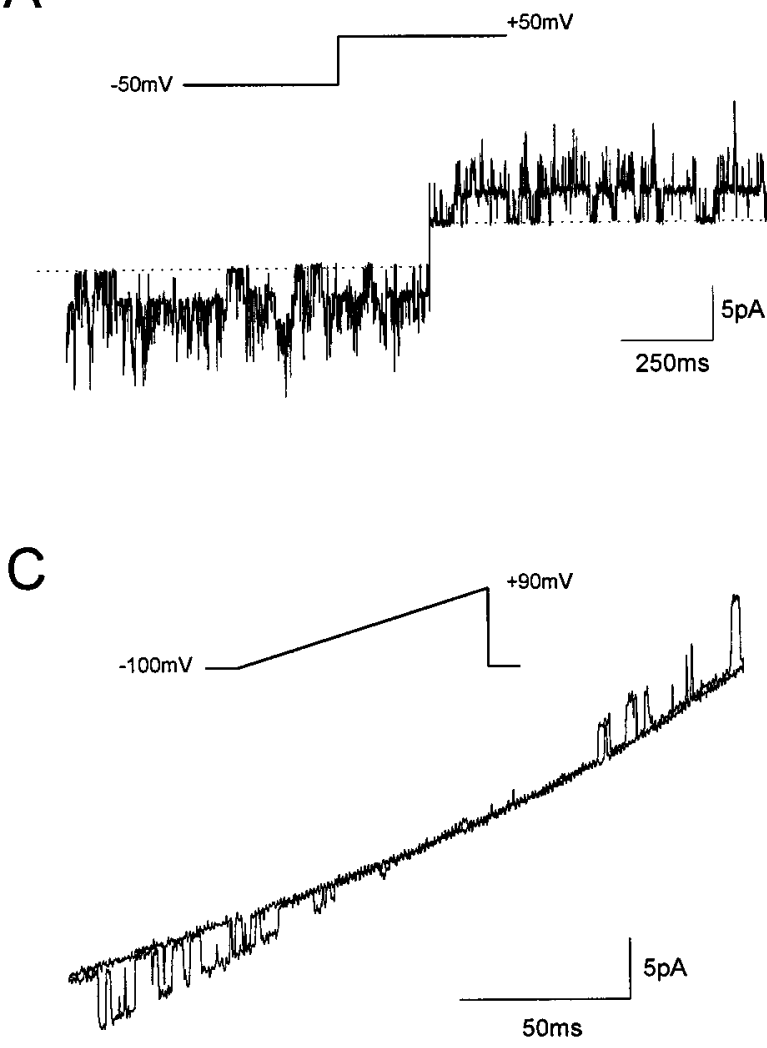

B

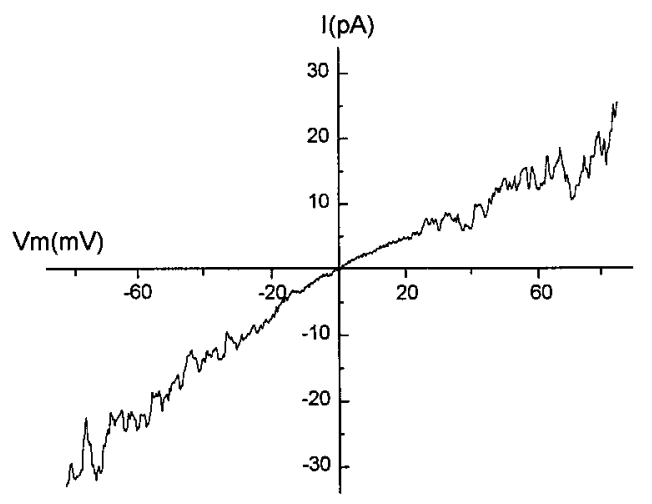

D

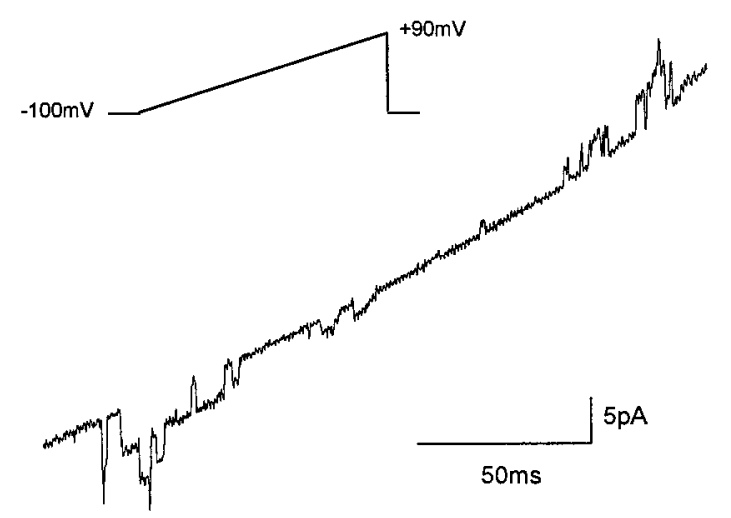

Figure 4. Voltage-dependence at the single-channel level cannot account for the macroscopic inward rectification. $A$, Representative trace showing $\alpha_{4} \beta_{2}$ single-channel recordings from an outside-out patch while $V_{\mathrm{m}}$ was stepped between -50 and $+50 \mathrm{mV}\left(1 \mathrm{sec}\right.$ at each $\left.V_{\mathrm{m}}\right)$. Dotted lines mark the zero current level. $B$, This trace shows currents recorded from an outside-out macropatch expressing $\alpha_{4} \beta_{2}$ nAChR subtypes. The current was recorded in response to $200 \mathrm{~nm}$ ACh while $V_{\mathrm{m}}$ was ramped from -85 to $+85 \mathrm{mV}$ at $1 \mathrm{~V} / \mathrm{sec}$. The $I-V$ curve was obtained by subtracting the current after run-down of single-channel activity from the current obtained $30 \mathrm{sec}$ after excision of the patch. $C$, This trace shows two superimposed $\alpha_{4} \beta_{2}$ single-channel recordings from an outside-out patch while the $V_{\mathrm{m}}$ was ramped from -100 to $+90 \mathrm{mV}(1 \mathrm{~V} / \mathrm{sec})$. These traces were obtained in the continuous presence of $100 \mathrm{nM}$ ACh. $D$, This figure shows single-channel currents from an outside-out patch expressing $\alpha_{4} \beta_{2} \mathrm{E} 260(\mathrm{ACh}=200 \mathrm{nM})$ while $V_{\mathrm{m}}$ was ramped from -100 to $+90 \mathrm{mV}(1 \mathrm{~V} / \mathrm{sec})$. For this patch, $1 \mathrm{~mm} \mathrm{Mg}^{2+}$ had been added to the recording pipette. Note: outward single-channel openings at positive membrane potentials are smaller than those in control recordings, suggesting a moderate block by intracellular $\mathrm{Mg}^{2+}$.

both $\alpha_{4} \beta_{2}$ and $\alpha_{4} \beta_{2}$ E260 receptors (Fig. $4 D$ ) or on $p_{\text {open }}$ at depolarized potentials (data not shown). These findings confirm previous results that intracellular $\mathrm{Mg}^{2+}$ is not a mediator of inward rectification of macroscopic ACh-evoked currents.

\section{Intracellular spermine blocks neuronal nAChRs expressed in Xenopus oocytes}

Recent studies have reported that intracellular spermine, an intracellular polyamine, can block inwardly rectifying $\mathrm{K}^{+}$channels and AMPA and kainate receptors in a voltage-dependent manner (Ficker et al., 1994; Bowie and Mayer, 1995; Fakler et al., 1995; Kamboj et al., 1995). We investigated whether spermine also blocks neuronal nAChRs. To test this, we recorded singlechannel currents from $\alpha_{4} \beta_{2}$ and $\alpha_{4} \beta_{2}$ E260 receptors in outsideout patches with different concentrations of spermine (100 nM to $100 \mu \mathrm{M}$ ) added to the pipette solution. Figure $5 A$ shows an example of single-channel currents for $\alpha_{4} \beta_{2} \mathrm{E} 260$ receptors recorded with $33 \mu \mathrm{M}$ spermine in the recording electrode; the presence of $33 \mu \mathrm{M}$ spermine abolished single-channel current at holding potentials $>0 \mathrm{mV}$. At lower concentrations $(1-3.3 \mu \mathrm{M})$, spermine reduced the amplitude of the single-channel openings (Fig. $5 B$ ). The fact that the outward currents are reduced in size, as seen in Figure $5 B$, suggests that spermine acts with fast kinetics
(Hille, 1992). The single-channel $I-V$ curves for $\alpha_{4} \beta_{2}$ receptors obtained from 14 outside-out patches in the presence of three different spermine concentrations are shown in the Figure $5 C$; for concentrations of spermine $\geq 10 \mu \mathrm{M}$, outward currents are abolished for $V_{\mathrm{m}}$ from $0 \mathrm{mV}$ to $+50 \mathrm{mV}$. In addition, comparison of data in control solutions clearly shows that spermine causes some reduction of the inward current at negative $V_{\mathrm{m}}$. The effects of spermine on the single-channel $I-V$ curves of $\alpha_{4} \beta_{2}$ and $\alpha_{4} \beta_{2} \mathrm{E} 260$ receptors $(n=12)$ were similar.

The effects of spermine are voltage- and concentrationdependent. Figure $6 A$ shows the single-channel $G-V$ relationship for $\alpha_{4} \beta_{2}$ receptors with increasing spermine concentrations. At each $V_{\mathrm{m}}$, every point represents the single-channel conductance in the presence of spermine as a fraction of the control; all points are normalized to their single-channel conductance at $-100 \mathrm{mV}$. In control solutions without spermine, the single-channel conductance shows slight outward rectification. However, with spermine in the recording electrode the single-channel conductance decreases with depolarization in a sigmoidal manner and falls to near zero at positive potentials (except for spermine concentrations $<3.3 \mu \mathrm{M})$. Higher concentrations of spermine result in parallel leftward shifts of the $G-V$ curves. With spermine concen- 
A $\alpha_{4} \beta_{2} E 260$

\section{$33 \mu \mathrm{M}$ Spermine}

$\mathrm{Vm}(\mathrm{mV})$

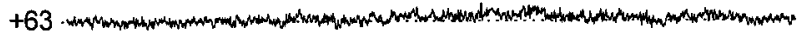

+40 .

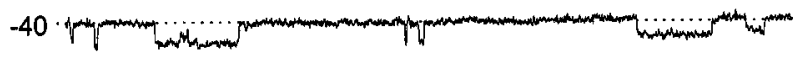

$\mathrm{B} \alpha_{4} \beta_{2}$

\section{$1 \mu \mathrm{M}$ Spermine}

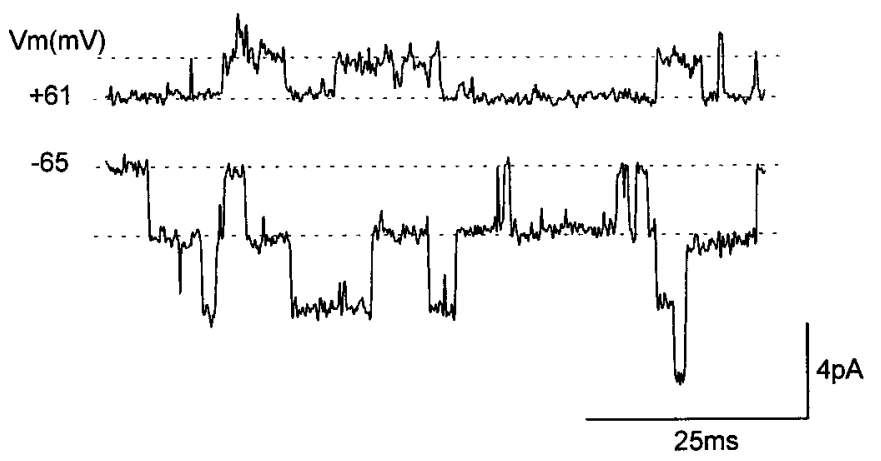

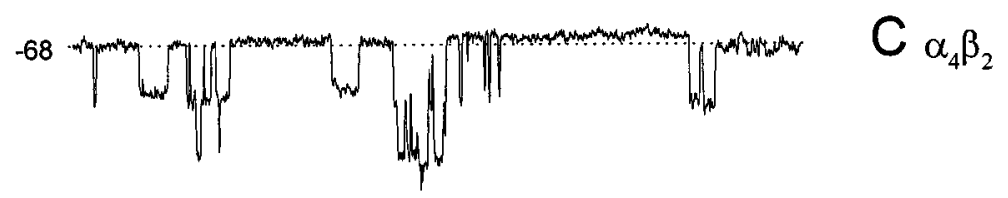
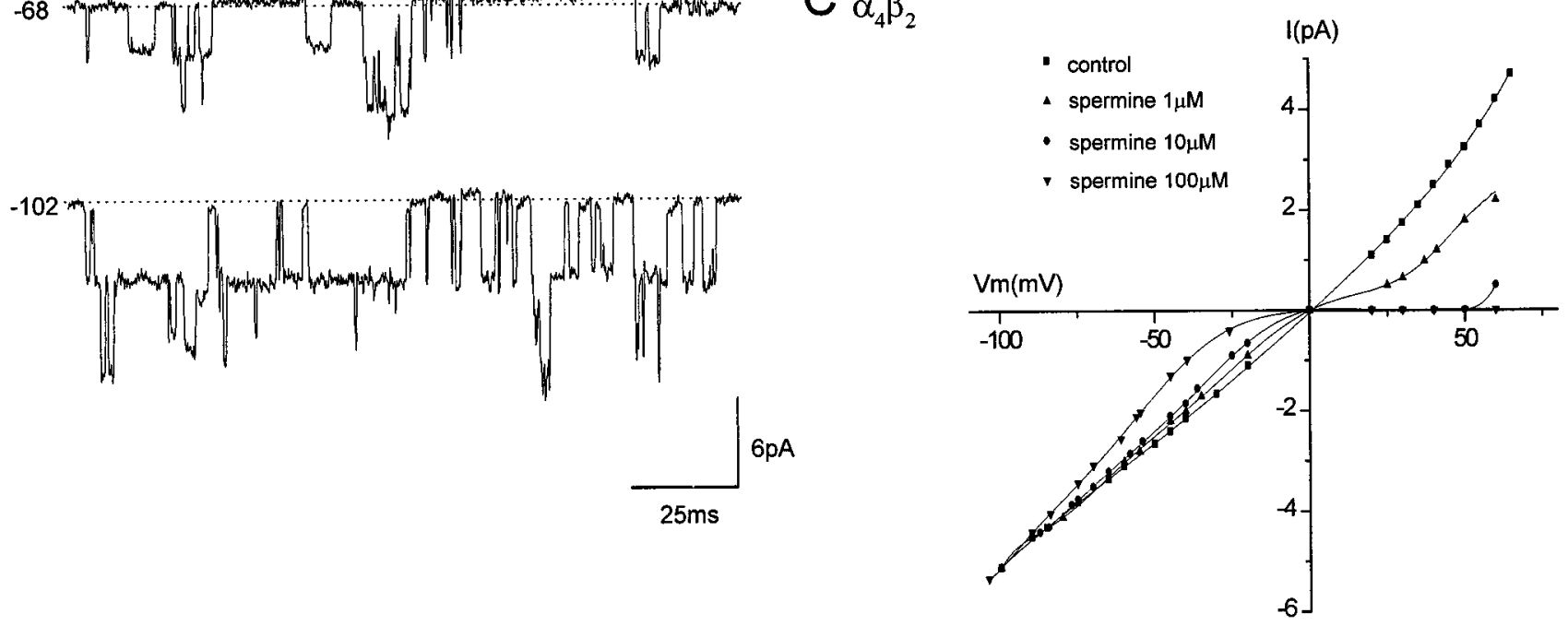

Figure 5. Spermine causes inward rectification of ACh-evoked currents in outside-out patches. $A$, These traces are outside-out single-channel recordings (100 nM ACh) at different holding potentials from an oocyte expressing $\alpha_{4} \beta_{2} \mathrm{E} 260$ receptors with $33 \mu \mathrm{M}$ spermine added to the intracellular pipette solution. Dotted lines mark the zero current level. $B$, This figure shows outside-out recordings $(\mathrm{ACh}=100 \mathrm{nM})$ from an oocyte expressing $\alpha_{4} \beta_{2}$ receptors with $1 \mu \mathrm{m}$ spermine added to the recording electrode; the outward $\alpha_{4} \beta_{2}$ single-channel currents at $+60 \mathrm{mV}$ are reduced by $\sim 40 \%$. Dotted lines mark the first open channel level for each trace. $C$, This figure shows the steady-state single-channel $I-V$ relationship for $\alpha_{4} \beta_{2}$ receptors in the absence ( $\mathbf{\square} ; n=$ 12) or in the presence of $1 \mu \mathrm{M}(\mathbf{\Delta} ; n=4), 10 \mu \mathrm{M}(\mathbf{-} ; n=6)$, or $100 \mu \mathrm{M}(\mathbf{\nabla} ; n=4)$ spermine in the recording electrode. I-V plots show progressive inward rectification of single-channel current with increasing concentrations of intracellular spermine. Solid lines are polynomial fits.

trations $>3.3 \mu \mathrm{M}$, the sigmoidal $G-V$ curve at the single-channel level resembled the $G-V$ curves measured at the macroscopic level (compare with Fig. 2), suggesting that the voltage-dependent block by intracellular spermine may underlie the inward rectification observed for the whole-cell ACh-evoked currents. At membrane potentials positive to $+50 \mathrm{mV}(+20 \mathrm{mV}$ for $<3.3 \mu \mathrm{M}$ spermine), we observed an increase in the conductance. Small outward currents were also apparent at these potentials at the whole-cell level (data not shown).

To analyze the effects of spermine at the single-channel level, we used a derivation of the Woodhull model (Eq. 1) for voltagedependent ion channel block (Woodhull, 1973; Johnson and Ascher, 1990):

$$
G / G_{\max }=1 /\left\{1+[S] / K_{\mathrm{d}}\right\}
$$

where

$$
K_{\mathrm{d}}=K_{\mathrm{d}(0)} \exp \left\{-V_{\mathrm{m}} z \delta F /[R T]\right\}
$$

and $[S]$ is the internal spermine concentration, $K_{\mathrm{d}}$ is the dissociation constant at a given $V_{\mathrm{m}}, K_{\mathrm{d}(0)}$ is the dissociation constant at $0 \mathrm{mV}, z$ is the valence of spermine, $\delta$ is the fraction of the membrane electrical field sensed by spermine from the intracellular side, and $R, T$, and $F$ refer to the universal gas constant, the absolute temperature, and the Faraday constant, respectively.

The solid lines in Figure $6 \mathrm{~A}$ show that Equation 1 provides a good description of the single-channel $G-V$ curves. Assuming the valence of spermine, $z$, to be 3.8 at physiological $\mathrm{pH}$ (Bowie and Mayer, 1995), this analysis estimates $K_{\mathrm{d}(0)}$ and $\delta$ to be $3.64 \pm 0.25$ $\mu \mathrm{M}$ and $51 \%$, respectively $(z \delta=1.93 \pm 0.3)$, and is based on data from 25 outside-out patches expressing $\alpha_{4} \beta_{2}$ receptors at eight different concentrations of spermine. Analysis of the spermine block of $\alpha_{4} \beta_{2} \mathrm{E} 260$ receptors gave very similar results: $K_{\mathrm{d}(0)}=$ $3.58 \pm 0.20$ and $z \delta=1.85$. Figure $6 B$ shows the effects of $V_{\mathrm{m}}$ on the affinity of the receptor for spermine $\left(K_{\mathrm{d}}\right)$. Within a range of $V_{\mathrm{m}}$ from $-80 \mathrm{mV}$ to $+30 \mathrm{mV}$, the concentration-dependent block 


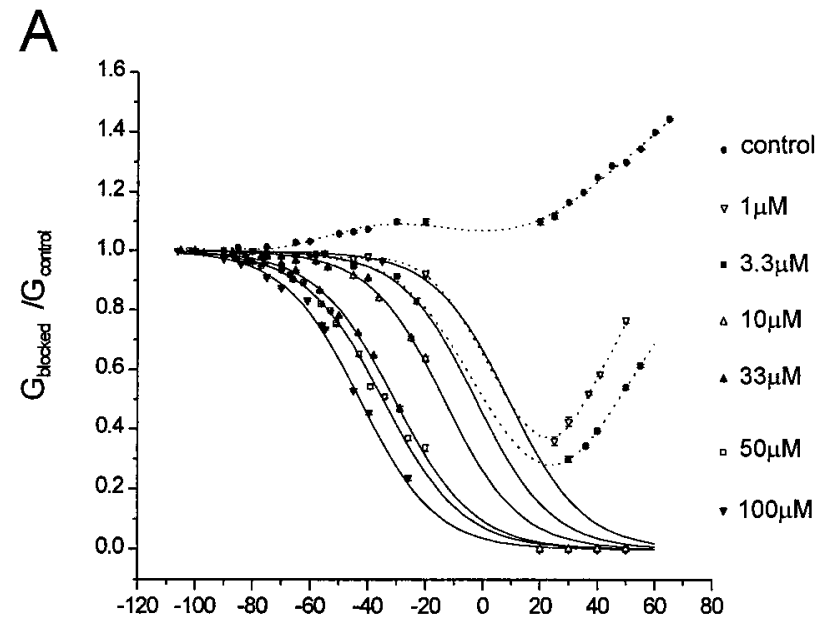

$\mathrm{Vm}(\mathrm{mV})$

B

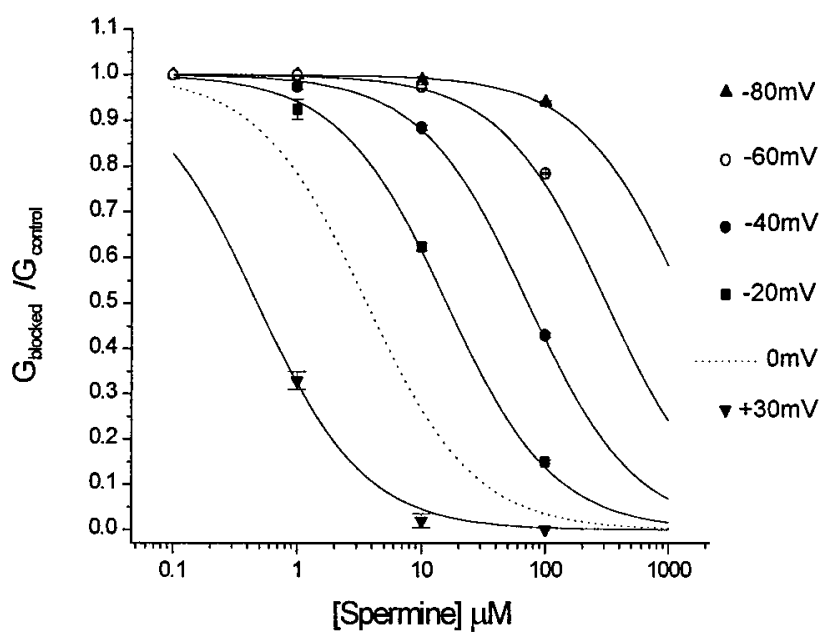

C

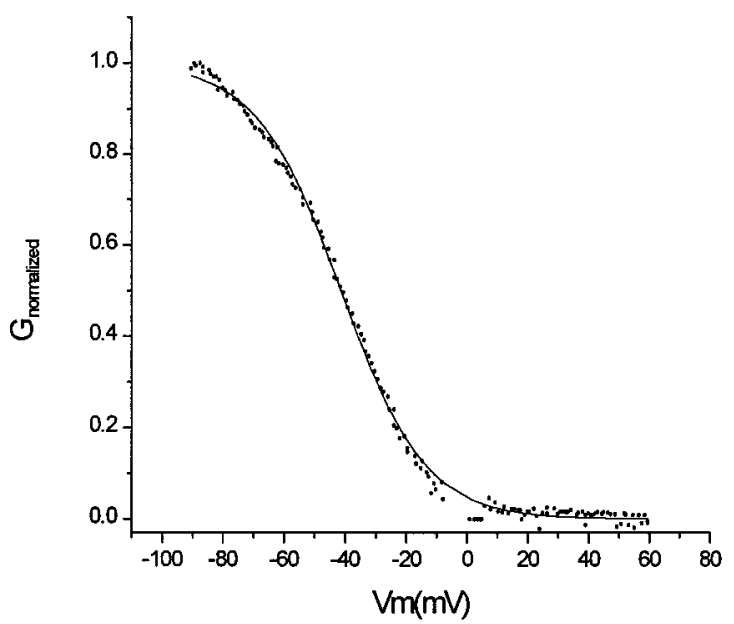

Figure 6. Analysis of voltage- and concentration-dependent block by intracellular spermine. $A$, This figure shows single-channel $G-V$ relationships for $\alpha_{4} \beta_{2}$ in the absence or the presence of $1,3.3,10,33,50$, or 100 $\mu \mathrm{M}$ spermine in the recording electrode. Single-channel conductance in control patches increased with depolarization $(n=14)$, whereas singlechannel conductance in the presence of spermine progressively by spermine was well described by a single binding isotherm (Fig. 6, solid lines), with the $K_{\mathrm{d}}$ decreasing with increasing depolarization: $1399,316,71.4,16.1,3.64$, and $0.39 \mu \mathrm{M}$ for $-80,-60,-40$, $-20,0$, and $+30 \mathrm{mV}$, respectively. These values are comparable to those for recombinantly expressed AMPA and kainate receptors (Bowie and Mayer, 1995).

Using the values for $z \delta$ and $K_{\mathrm{d}(0)}$ from the single-channel measurements above, we fit the $G-V$ curves for macroscopic $\mathrm{ACh}$-evoked currents for $\alpha_{4} \beta_{2}$ receptors using Equation 1. Figure $6 C$ shows that Equation 1 describes the data well assuming an intracellular spermine concentration $[S]$ of $82 \mu \mathrm{M}(n=8)$. It should be noted that this fit does not take into account the possible contribution of other polyamines such as spermidine and putrescine or the moderate voltage-dependent decrease in singlechannel $p_{\text {open }}$.

\section{Spermine blocks native neuronal nAChRs on sympathetic neurons}

Our results on recombinant receptors indicated that intracellular spermine blocks neuronal nAChRs in a voltage-dependent manner, thereby producing inward rectification of the ACh-evoked currents. To determine whether spermine has a similar action on native receptors expressed on neurons, we examined the effects of intracellular spermine on $\mathrm{nAChRs}$ expressed by sympathetic neurons. Figure $7 A$ shows that single nAChR currents measured in cell-free outside-out patches flow in both directions equally well, as has been reported previously (Mathie et al., 1990). The singlechannel conductance measured in outside-out patches from SCG neurons was $32.5 \pm 1.35 \mathrm{pS}$ at $-60 \mathrm{mV}(n=12)$. Spermine (100 $\mu \mathrm{M})$ added to the recording electrode, completely abolished single-channel current at $V_{\mathrm{m}}>0 \mathrm{mV}$ (Fig. $7 B$ ). These results suggest that intracellular spermine in sympathetic neurons can block nAChRs from the inside and produce inward rectification of the ACh-evoked currents. We plotted the single-channel $I-V$ curves using data from seven control outside-out patches and four outside-out patches in the presence of spermine (Fig. $7 C$ ). The control $I-V$ curve shows slight outward rectification, whereas the single-channel $I-V$ curve in the presence of $100 \mu \mathrm{M}$ spermine exhibits a strong inward rectification, similar to that seen at the macroscopic level (compare with Fig. 1B). We also measured $\mathrm{ACh}$-evoked currents in outside-out macropatches. As shown in Figure $7 D$, in the presence of spermine $(100 \mu \mathrm{M})$ the ACh-evoked current from a macropatch shows strong inward rectification.

Figure $8 A$ shows the $G-V$ plot obtained from four outside-out patches of SCG neurons with $100 \mu \mathrm{M}$ spermine added to the recording electrode. Similar to our results for $\alpha_{4} \beta_{2}$ receptors, the

\footnotetext{
$\leftarrow$

decreased with depolarization. Increasing the concentration of spermine causes a leftward shift of the $G-V$ relationship. Solid lines are fits to data points using Equation 1. Points represent the single-channel conductance in the presence of spermine as a fraction of the control conductance for each holding potential; all points are normalized to the conductance at $-100 \mathrm{mV}$. Data are obtained from three to six outside-out patches for each spermine concentration (mean $\pm \mathrm{SE}$ ). Dotted lines are polynomial fits to the data. $B$, This figure shows the concentration-response relationship for spermine at different holding potentials. Affinity of spermine for $\alpha_{4} \beta_{2}$ receptor is increased with depolarization. Data points are derived from $A$, and solid lines are fits using Equation 1. The dotted line is the theoretical fit at $0 \mathrm{mV}$ predicted by Equation 1. $C$, This figure shows a representative $G-V$ plot of the macroscopic ACh-evoked current recorded from an oocyte expressing $\alpha_{4} \beta_{2}$ receptors. We fit this $G-V$ curve with Equation 1, using the $K_{\mathrm{d}(0)}$ and $z \delta$ values obtained from singlechannel analysis (solid line).
} 

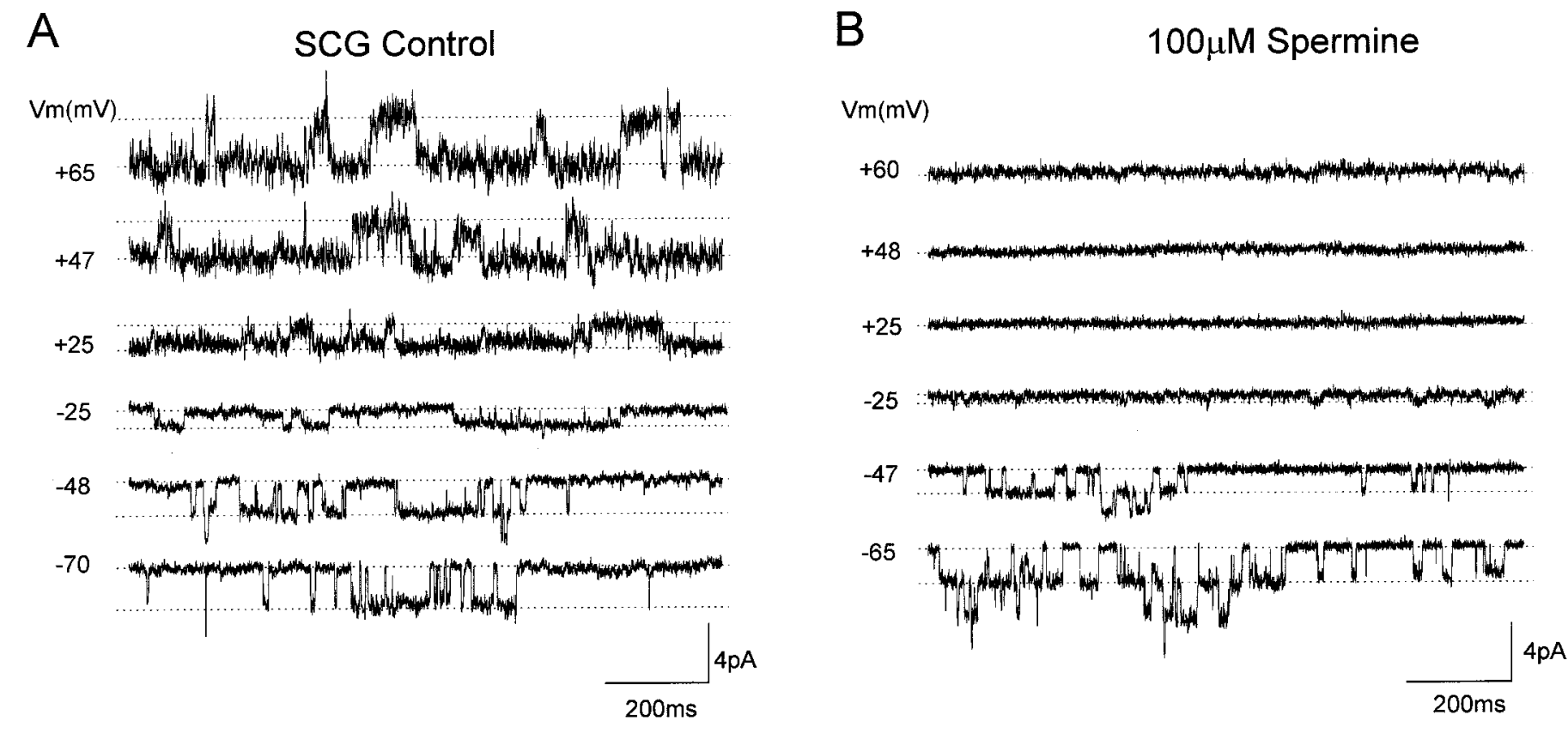

C
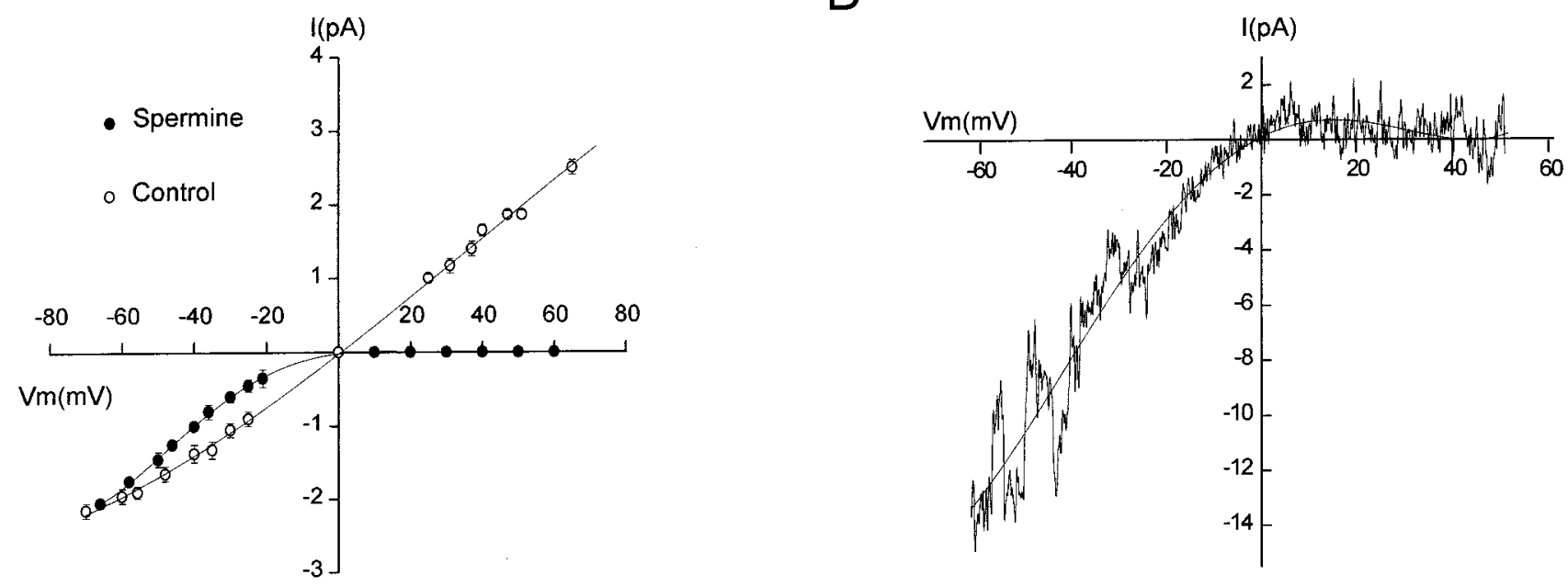

Figure 7. Intracellular spermine blocks native SCG nAChRs at the single-channel level. $A$, This figure shows single-channel recordings obtained from an SCG neuron in an outside-out patch; native SCG nAChRs show both inward and outward currents in response to $20 \mu \mathrm{M}$ ACh. Dotted lines mark the zero current and the first open state. $B$, Outside-out single-channel recordings from another SCG neuron with $100 \mu \mathrm{M}$ spermine added to the recording electrode. Spermine $(100 \mu \mathrm{M})$ completely blocked the outward single-channel openings and reduced the amplitude of the inward openings $([\mathrm{ACh}]=20$ $\mu \mathrm{M})$. At positive potentials, dotted lines mark the baseline, and at negative potentials, dotted lines mark the baseline and the first open state. $C$, This figure shows ACh-evoked single-channel $I-V$ curves obtained from outside-out patches from SCG neurons. The control $I-V$ curve $(O ; n=7)$ exhibits slight outward rectification, similar to recombinant neuronal nAChRs (Fig. 3B,D,F). In the presence of $100 \mu \mathrm{M}$ spermine in the recording electrode $(\bullet ; n=$ 4), however, the $I-V$ relationship exhibits strong inward rectification. Single-channel amplitudes were measured in both steady-state and ramp experiments, and points represent mean \pm SE. Solid lines are polynomial fits. $D$, This figure shows the current in response to $20 \mu \mathrm{M}$ ACh recorded from an outside-out macropatch from an SCG neuron in the presence of $100 \mu \mathrm{M}$ spermine in the recording electrode. The current was recorded while $V_{\mathrm{m}}$ was ramped from -60 to $+50 \mathrm{mV}$ (at $1 \mathrm{~V} / \mathrm{sec}$ ). The solid line is a polynomial fit.

block by spermine of native SCG nAChRs increases as the membrane is depolarized in a sigmoidal manner. Using Equation 1, we fit this single-channel $G-V$ curve and estimated $K_{\mathrm{d}(0)}$ and $\delta$ to be $4.27 \pm 0.6 \mu \mathrm{M}$ and $65 \%$, respectively (with $z \delta$ being $2.48 \pm 0.16$ ). These results suggest that spermine has comparable affinity for $\alpha_{4} \beta_{2}$ receptors and native nAChRs expressed on SCG neurons.

Using the parameters obtained from the single-channel analysis, we analyzed the macroscopic ACh-evoked currents in SCG neurons. In Figure $8 B$, we transformed a whole-cell ACh-evoked
$I-V$ curve into a $G-V$ curve, assuming a reversal potential of -5 $\mathrm{mV}$ (our unpublished observations) for ACh-evoked currents in SCG neurons. The macroscopic chord conductance progressively decreases as $V_{\mathrm{m}}$ is depolarized from $-65 \mathrm{mV}$ (Fig. $8 B$ ). We used Equation 1 to fit the whole-cell ACh-evoked $G-V$ curves using $K_{\mathrm{d}(0)}$ and $\delta$ as determined at the single-channel level (Fig. $8 B$, solid line). Results from eight different experiments estimated the intracellular spermine concentration, $[S]$, to be $51 \mu \mathrm{M}$. The exact concentration of free spermine in rat sympathetic neurons has not 
A

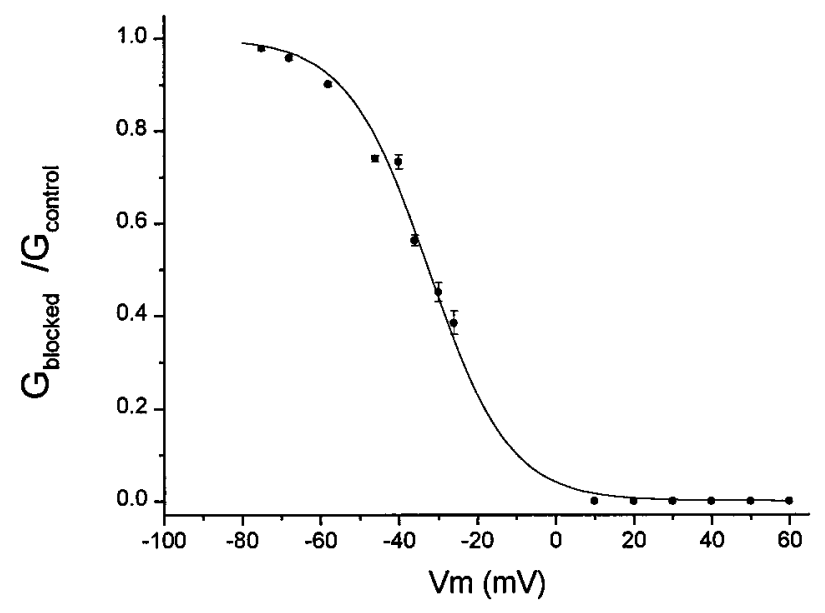

B

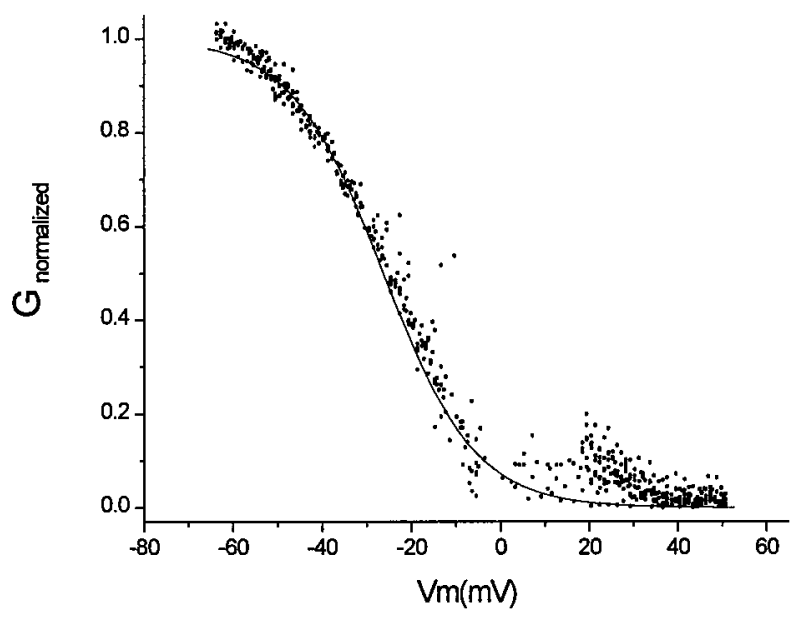

Figure 8. Block by intracellular spermine underlies the inward rectification of macroscopic ACh-evoked currents in SCG neurons. $A$, This figure shows the single-channel $G-V$ plot for native SCG nAChRs in the presence of $100 \mu \mathrm{M}$ spermine. The single-channel conductance shows a progressive decrease with depolarization. Points represent the singlechannel cord conductance (mean $\pm \mathrm{SE} ; n=4$ ) in the presence of spermine as a fraction of the control single-channel conductance at every potential; all values were normalized to the conductance at $-75 \mathrm{mV}$. The solid line is the fit to the data using Equation 1. B, This figure represents the whole-cell $G-V$ plot obtained from an SCG neuron. Similar to the single-channel conductance in the presence of spermine, the macroscopic ACh-evoked conductance in SCG neurons shows a progressive decrease with depolarization. The solid line is a fit to these data using Equation 1. This fit was performed using values for $K_{\mathrm{d}(0)}$ and $z \delta$ from single-channel analysis (see Results).

been determined, but the value predicted from Equation 1 is within the range measured for other mammalian cells (Watanabe et al., 1991) and comparable to that estimated in human embryonic kidney cells using similar analysis for kainate receptors (Bowie and Mayer, 1995).

\section{Extracellular spermine blocks neuronal nAChRs}

Extracellular polyamines have been shown to block both native and recombinant AMPA receptors (Robichaud and Boxer, 1993;
Washburn and Dingeldine, 1996). Therefore, we asked whether extracellular spermine can also block neuronal nAChRs and whether this effect is similar to the voltage-dependent block produced by intracellular spermine. Extracellular spermine blocked the inward $\mathrm{ACh}$-evoked currents in oocytes expressing $\alpha_{4} \beta_{2}$ (Fig. 9A). Co-application of $33 \mu \mathrm{M}$ spermine with $1 \mu \mathrm{M} \mathrm{ACh}$ in the extracellular solution resulted in a $\sim 45 \%$ block of the macroscopic ACh-evoked inward current recorded from $\alpha_{4} \beta_{2}$ receptors (Fig. 9A).

To examine the voltage-dependence, we measured the block when ramping the membrane potential from $-90 \mathrm{mV}$ to $+50 \mathrm{mV}$. Figure $9 B$ shows the ACh-evoked $I-V$ curves for $\alpha_{4} \beta_{2}$ receptors in the absence or presence of $33 \mu \mathrm{M}$ extracellular spermine. The form of the typical inward rectification of the $I-V$ curve is not affected by extracellular spermine. We also plotted the changes in macroscopic conductance (as a fraction of the control conductance) of the receptor versus membrane potential in the presence of $33 \mu \mathrm{M}$ spermine (Fig. $9 C$ ). As is apparent from this $G-V$ plot, the blocking effect of extracellular spermine shows little voltagedependence. To test whether extracellular spermine can act as a competitive antagonist, we examined the effect of increasing concentrations of $\mathrm{ACh}$ on the block by extracellular spermine. The blocking effect of $50 \mu \mathrm{M}$ extracellular spermine on inward currents evoked by either $0.1,1$, or $10 \mu \mathrm{M} \mathrm{ACh}$ in $\alpha_{4} \beta_{2}$-expressing oocytes was not significantly different $(n=5)$.

We tested the effect of $1 \mathrm{~nm}$ to $1 \mathrm{~mm}$ extracellular spermine on ACh-evoked currents in oocytes expressing $\alpha_{3} \beta_{4}, \alpha_{4} \beta_{2}$, or $\alpha_{4} \beta_{2} \mathrm{E} 260$. The inhibition curves for all three receptors were well described by a single binding site isotherm according to the equation: $I=I_{\max } /\left(1+[S] / \mathrm{IC}_{50}\right)$, where $I$ is the current measured at any $V_{\mathrm{m}}$ in the presence of spermine, $I_{\max }$ is the current at the same $V_{\mathrm{m}}$ in the absence of spermine, $[S]$ is the concentration of extracellular spermine, and $\mathrm{IC}_{50}$ is the concentration of spermine for half-maximal inhibition. The extracellular block by spermine was concentration-dependent, with an $\mathrm{IC}_{50}$ of $40.3 \pm$ $3.8 \mu \mathrm{M}(n=7)$ (Fig. 9D) for $\alpha_{4} \beta_{2}$ receptors. We obtained similar results for $\alpha_{3} \beta_{4}(42.3 \pm 4.3 \mu \mathrm{M} ; n=5)$ and $\alpha_{4} \beta_{2} \mathrm{E} 260(39.5 \pm 2.7$ $\mu \mathrm{M} ; n=6$ ) expressed in oocytes (data not shown).

\section{DISCUSSION}

In this study, we investigated mechanisms involved in the strong inward rectification of neuronal nAChRs. Our results demonstrate that spermine blocks neuronal nAChRs with high affinity at depolarized membrane potentials when acting on the cytoplasmic side of the channel. Given the high concentration of free spermine in neurons, the voltage-dependent block by intracellular spermine likely underlies inward rectification of neuronal nAChRs.

We examined the effects of spermine on three different subtypes of neuronal nAChRs: recombinant $\alpha_{3} \beta_{4}$ and $\alpha_{4} \beta_{2}$ receptors expressed in Xenopus oocytes, and native receptors expressed by SCG neurons. At the whole-cell level, we demonstrated that the ACh-evoked currents for all three receptors exhibit strong inward rectification, consistent with previously published reports (Bertrand et al., 1990; Mathie et al., 1990; Ifune and Steinbach, 1992; Sands and Barish, 1992). Furthermore, at the single-channel level, we showed that this inward rectification is abolished in cell-free outside-out patches, as shown for neuronal nAChRs expressed on SCG neurons and PC12 cells (Mathie et al., 1990; Neuhaus and Cachelin, 1990; Ifune and Steinbach, 1992; Sands and Barish, 1992).

Intracellular spermine has been shown to underlie inward rec- 
A

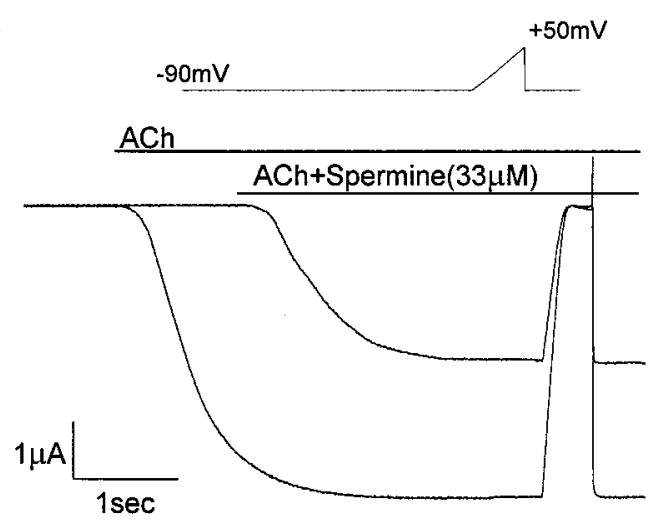

C

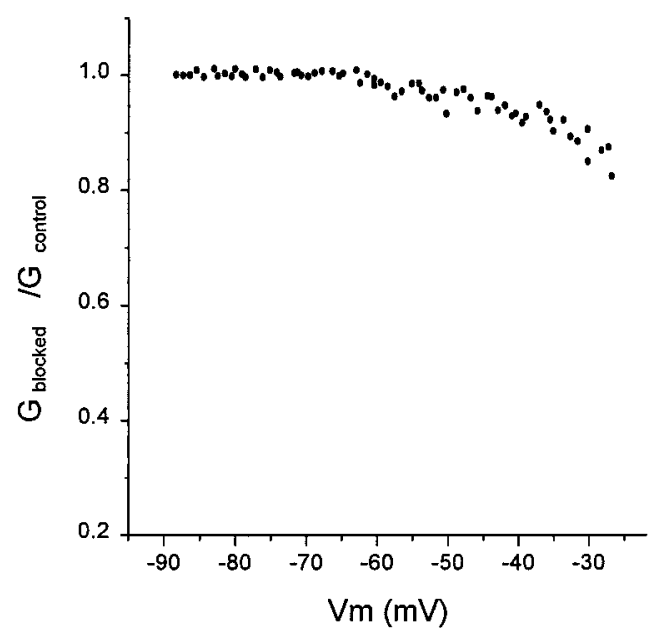

B
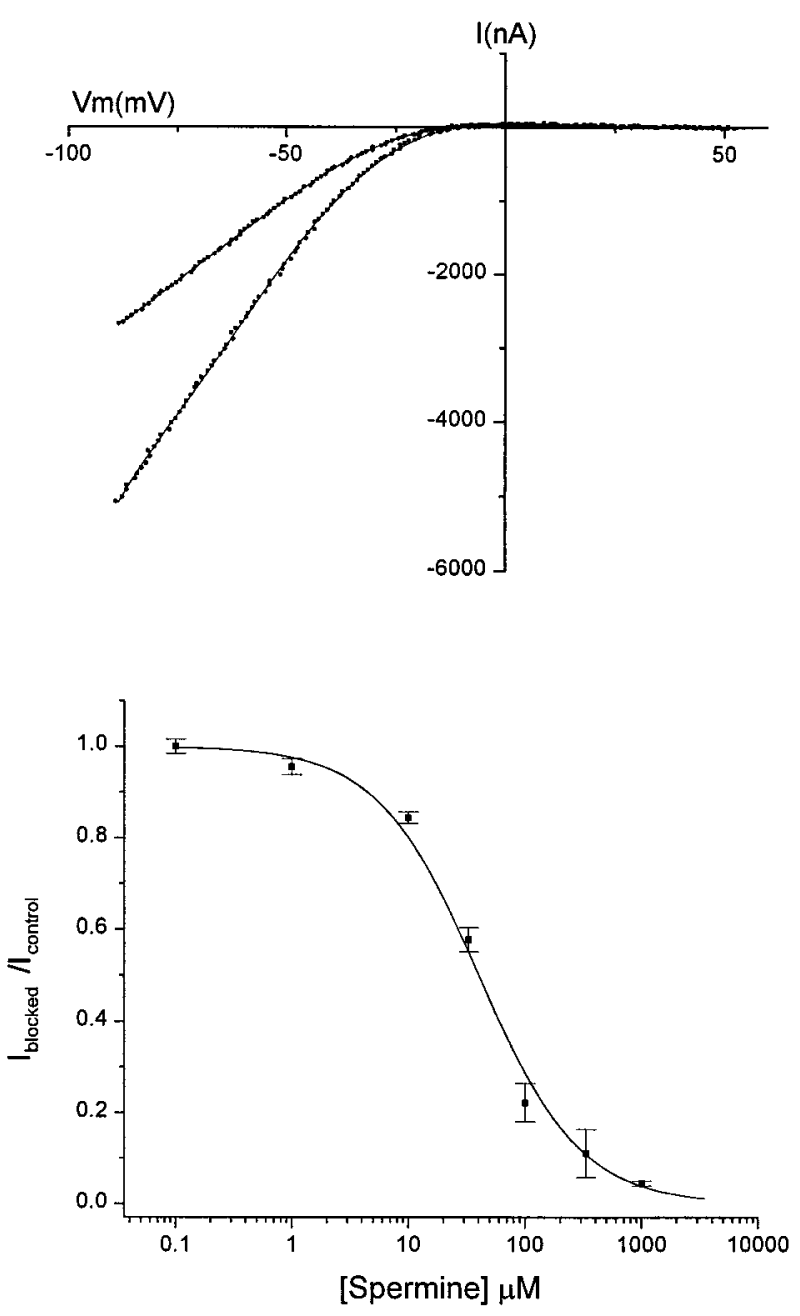

Figure 9. Extracellular spermine blocks macroscopic ACh-evoked inward currents. $A$, This figure shows inward ACh-evoked currents recorded from an oocyte expressing $\alpha_{4} \beta_{2}$ in the absence and the presence of extracellular spermine. At $-90 \mathrm{mV}, 33 \mu \mathrm{M}$ extracellular spermine blocks the current in response to $1 \mu \mathrm{M}$ ACh by $45 \%$. B. Macroscopic $I-V$ relationship for the oocyte in $A$ is plotted in the presence and absence of $33 \mu \mathrm{M}$ extracellular spermine. Inward rectification is not affected by extracellular spermine. $C$, This figure shows the change in the macroscopic conductance versus the membrane potential in the presence of $33 \mu \mathrm{M}$ extracellular spermine. The conductance in the presence of spermine is shown as a fraction of the control conductance at every membrane potential and then normalized to the conductance at $-90 \mathrm{mV}$. $D$, This figure shows the inhibition curve for $\alpha_{4} \beta_{2}$ receptors with increasing concentrations of extracellular spermine. Extracellular spermine blocks the ACh-evoked current in $\alpha_{4} \beta_{2}$-expressing oocytes in a concentration-dependent manner. Each spermine concentration was tested on at least seven oocytes (mean \pm SE). Solid line is a fit for a single binding site isotherm (see Results).

tification of glutamate receptors (Bowie and Mayer, 1995) and inwardly rectifying $\mathrm{K}^{+}$channels (Fakler et al., 1995); therefore, we examined the effects of intracellular spermine on neuronal nAChRs. In outside-out recordings, we found that the addition of spermine $(0.1-100 \mu \mathrm{M})$ to the recording pipette produced a voltage-dependent block of neuronal nAChRs in a concentrationdependent manner. To analyze the spermine block, we fit the single-channel $G-V$ curves to a derivation of the Woodhull model (Woodhull, 1973). According to this model, spermine enters the open receptor and binds to a site within the membrane electrical field. Spermine at this site interferes with the movement of small cations through the channel pore, and the occupancy of this site by spermine is affected by changes in membrane potential. This analysis gave a $K_{\mathrm{d}(0)}$ of $3.6 \mu \mathrm{M}$ and a $z \delta$ of 1.9 for $\alpha_{4} \beta_{2}$ receptors and a $K_{\mathrm{d}(0)}$ of $4.3 \mu \mathrm{M}$ and a $z \delta$ of 2.5 for nAChRs on SCG neurons, suggesting that the spermine binding site is located at 51 or $65 \%$ of the membrane electrical field, respectively. These values are comparable to those measured for kainate receptors $\left(K_{\mathrm{d}(0)}=5.5\right.$ $\mu \mathrm{M}$ and $z \delta=2.5)$ and AMPA receptors $\left(K_{\mathrm{d}(0)}=1.5 \mu \mathrm{M}\right)$ (Bowie and Mayer, 1995).

Using the Woodhull model with the above parameters, we were able to describe the $G-V$ relationships for whole-cell ACh-evoked currents and estimate the free intracellular spermine in oocytes $(82 \mu \mathrm{M})$ and SCG neurons $(51 \mu \mathrm{M})$. These values are well within the range (50-200 $\mu \mathrm{M})$ of physiological free spermine concentrations (Watanabe et al., 1991; Bowie and Mayer, 1995; Traynelis et al., 1995). Although our analysis suggests that spermine alone is capable of conferring rectification to ACh-evoked currents in neurons, it is possible that other polyamines such as spermidine and putrescine contribute to the action of spermine.

The model also assumes that spermine does not pass through the channel (Woodhull, 1973). This model describes our data well for membrane potentials from $-100 \mathrm{mV}$ to $+50 \mathrm{mV}$. However, at membrane potentials $>50 \mathrm{mV}$ (or $+20 \mathrm{mV}$ for spermine $<3.3$ 
$\mu \mathrm{M})$, the ACh-evoked conductance increased, suggesting a relief of spermine block. One interpretation for such a relief of block is that at strongly depolarized potentials spermine permeates the pore; this unblocking allows small cations to flow out and gives rise to an outward current. A similar interpretation has also been suggested for AMPA and kainate receptors (Bowie and Mayer, 1995).

Previous work on native $\mathrm{nAChRs}$ on PC12 cells indicated that it was possible to reduce rectification of the whole-cell AChevoked current if the cells were dialyzed with 5-10 mM $\mathrm{Na}_{2} \mathrm{ATP}$ for up to $20 \mathrm{~min}$ (Sands and Barish, 1992; Ifune and Steinbach, 1993); $\mathrm{Mg}^{2+}$ chelators alone had little effect on rectification (Neuhaus and Cachelin, 1990; If une and Steinbach, 1993). This partial removal of rectification is likely caused by the chelation of polyamines by $\mathrm{Na}_{2} \mathrm{ATP}$ (Watanabe et al., 1991; Bowie and Mayer, 1995; Fakler et al., 1995). Our results are in agreement with this interpretation. Lowering spermine concentrations inside cells is technically difficult, however, because intracellular spermine is present at high concentrations and effectively buffered (Watanabe et al., 1991; Swaerd et al., 1997). The high concentration of intracellular bound spermine is in equilibrium with the intracellular free spermine (Gilad and Gilad, 1991; Watanabe et al., 1991); thus, reduction in the concentration of intracellular free spermine will cause the release of more spermine from the large pool of bound spermine. We attempted to chelate spermine in SCG neurons using whole-cell recordings with $10 \mathrm{~mm} \mathrm{Na}_{2} \mathrm{ATP}$ in the pipette; in the best cases, we observed only a $10-20 \%$ reduction of inward rectification after 15-20 min. One possibility for not observing a greater reduction is that spermine is effectively buffered in SCG neurons.

AMPA, kainate, neuronal nACh receptors, and inwardly rectifying $\mathrm{K}^{+}$channels are thought to have different membrane topologies (Hollmann et al., 1994; Karlin and Akabas, 1995; Nichols and Lopatin, 1997), yet they appear to use a common mechanism for inward rectification. In the case of the glutamate receptors, inward rectification and spermine sensitivity are unique properties of $\mathrm{Ca}^{2+}$-permeable receptor subtypes (Bowie and Mayer, 1995; Kamboj et al., 1995; Koh et al., 1995). By comparison, neuronal nAChRs, including the $\alpha$-bungarotoxinsensitive homomeric $\alpha_{7}$ receptors, are highly permeable to $\mathrm{Ca}^{2+}$ and exhibit strong inward rectification. For glutamate receptors, both $\mathrm{Ca}^{2+}$ permeability and inward rectification have been attributed to a glutamine (Q) residue in the M2 hydrophobic domain; substitution of this residue to a positively charged arginine $(\mathrm{R})$ renders the receptor $\mathrm{Ca}^{2+}$ impermeable and outwardly rectifying (Hume et al., 1991). There is evidence to suggest that a comparable site in the neuronal nAChRs may exist (Bertrand et al., 1993).

Inwardly rectifying AMPA and kainate receptors are blocked also by extracellular spermine (Washburn and Dingledine, 1996); therefore, we tested the effects of extracellular spermine on neuronal nAChRs. We demonstrated that extracellular spermine blocks ACh-evoked current for both $\alpha_{3} \beta_{4}$ and $\alpha_{4} \beta_{2}$ in a concentration-dependent manner, with an $\mathrm{IC}_{50}$ of $40-42 \mu \mathrm{M}$ for both receptors. The degree of block was largely independent of ACh concentration (100 nM to $10 \mu \mathrm{M})$ and, unlike the block by intracellular spermine, weakly voltage-dependent. To determine whether this block was sensitive to charges at the extracellular mouth of the pore, we investigated the effects of extracellular spermine on $\alpha_{4} \beta_{2}$ E260 receptors. We obtained a similar $\mathrm{IC}_{50}$ for $\alpha_{4} \beta_{2}$ E260 (39.5 $\left.\mu \mathrm{M}\right)$ compared with wild-type $\alpha_{4} \beta_{2}$, indicating that increasing negative charges in the extracellular ring of the channel does not affect the block. Our results suggest that extracellular spermine acts as a noncompetitive open channel blocker.

Neuronal nAChRs are more sensitive to block by extracellular spermine compared with AMPA and kainate receptors. Extracellular spermine blocks AMPA receptors with an $\mathrm{IC}_{50}$ of $120 \mu \mathrm{M}$ for GluR3 and an $\mathrm{IC}_{50}$ of $1000 \mu \mathrm{M}$ for GluR1 and GluR4, with little voltage dependence (Washburn and Dingledine, 1996). The effects of extracellular spermine on NMDA receptors are more complex: 1-30 $\mu \mathrm{M}$ extracellular spermine enhances the response of NMDA receptors (Williams et al., 1990; Rock and MacDonald, 1992; Benveniste and Mayer, 1993), whereas at higher concentrations $\left(\mathrm{IC}_{50}=344 \mu \mathrm{M}\right.$ at $\left.-60 \mathrm{mV}\right)$, extracellular spermine inhibits NMDA receptors in a voltage-dependent manner with a $K_{\mathrm{d}(0)}$ of $22.8 \mathrm{~mm}$ (Benveniste and Mayer, 1993).

Although normally the metabolism and excretion of polyamines are tightly regulated, extracellular levels of polyamines can vary in diseased states (Marton and Pegg, 1995; Williams, 1997) and likely increase after cell lysis. In such circumstances, micromolar changes in local extracellular spermine concentrations would affect neuronal nAChRs more than glutamate receptors. Recent studies have provided strong evidence that presynaptic nicotinic transmission modulates the release of neurotransmitters, including dopamine, GABA, and glutamate (McGehee and Role, 1995). Therefore, small changes in extracellular spermine could selectively block this modulation.

The voltage-dependent block of neuronal nAChRs by intracellular spermine plays important physiological roles. In the CNS, many nAChRs are thought to be located at presynaptic terminals (Role and Berg, 1996). When activated, these receptors depolarize the nerve terminal to modulate transmitter release. In the absence of inward rectification, the conductance increase produced by these receptors would reduce the amplitude of the nerve terminal action potential. The high-affinity block of nAChRs by intracellular spermine rapidly abolishes the conductance increase at positive membrane potentials, thereby allowing an effective depolarization of the terminal. The block by intracellular spermine also affects postsynaptic nAChRs on dendrites and cell bodies. The nonlinear ACh-evoked $G-V$ curves show a decrease in conductance even at membrane potentials near rest; therefore, changes in the membrane potential of the postsynaptic neuron can affect the conductance of the nAChRs and alter synaptic efficacy.

\section{REFERENCES}

Anand R, Conroy WG, Schoepfer R, Whiting P, Lindstrom J (1991) Neuronal nicotinic acetylcholine receptors expressed in Xenopus oocytes have a pentameric quaternary structure. J Biol Chem 226:11192-11198.

Benveniste M, Mayer ML (1993) Multiple effects of spermine on $N$-methyl-D-aspartic acid receptor responses of rat cultured hippocampal neurons. J Physiol (Lond) 464:131-163.

Bertrand D, Ballivet M, Rungger D (1990) Activation and blocking of neuronal nicotinic acetylcholine receptor reconstituted in Xenopus oocytes. Proc Natl Acad Sci USA 87:1993-1997.

Bertrand D, Cooper E, Valera S, Rungger D, Ballivet M (1991) Electrophysiology of neuronal nicotinic acetylcholine receptors expressed in Xenopus oocytes following nuclear injection of genes or cDNAs. Methods Neurosci 4:174-193.

Bertrand D, Galzi JL, Devillers-Thiéry A, Bertrand S, Changeux JP (1993) Mutations at two distinct sites within the channel domain M2 alter calcium permeability of neuronal a7 nicotinic receptor. Proc Natl Acad Sci USA 90:6971-6975.

Bowie D, Mayer ML (1995) Inward rectification of both AMPA and kainate subtype glutamate receptors generated by polyamine-mediated ion channel block. Neuron 15:453-462.

Boyd RT, Jacob MH, Couturier S, Ballivet M, Berg DK (1988) Expres- 
sion and regulation of neuronal acetylcholine receptor nRNA in chick ciliary ganglia. Neuron 1:495-502.

Cooper E, Couturier S, Ballivet M (1991) Pentameric structure and subunit stoichiometry of a neuronal nicotinic acetylcholine receptor. Nature 350:235-238.

Couturier S, Erkman L, Valera S, Rungger D, Bertrand S, Boulter J, Ballivet M, Bertrand D (1990) $\alpha_{5}, \alpha_{5}$ and non- $\alpha_{5}$ : three clustered avian genes encoding neuronal nicotinic acetylcholine receptor-related subunits. J Biol Chem 265:17560-17567.

Fakler B, Brandle U, Glowatzki E, Weidermann S, Zenner HP, Ruppersberg JP (1995) Strong voltage-dependent inward rectification of inward rectifier $\mathrm{K}^{+}$channels is caused by intracellular spermine. Cell 80:149-154.

Ficker E, Taglialatela M, Wible BA, Henley CM, Brown AM (1994) Spermine and spermidine as gating molecules for inward rectifier $\mathrm{K}^{+}$ channels. Science 266:1068-1072.

Flores CM, Rogers SW, Paberza LA, Wolfe BB, Kellar KJ (1992) A subtype of nicotinic cholinergic receptor in rat brain is composed of $\alpha_{4}$ and $\beta_{2}$ subunits and is up-regulated by chronic nicotine treatment. Mol Pharmacol 41:31-37.

Forster I, Bertrand D (1995) Inward rectification of neuronal nicotinic acetylcholine receptors investigated by using the homomeric 7 receptor. Proc R Soc Lond B Biol Sci 260:139-148.

Gilad GM, Gilad VH (1991) Polyamine uptake, binding and release in rat brain. Eur J Pharmacol 193:41-46.

Haghighi A, Cooper E (1997) Intracellular spermine underlies the inward rectification of $\alpha_{4} \beta_{2}$ neuronal nicotinic acetylcholine receptors expressed in Xenopus oocytes. Biophys Soc Abstr 72:A264-W84.

Hamill OP, Marty A, Neher E, Sakmann B, Sigworth F (1981) Improved patch clamp techniques for high resolution current recording from cells and cell-free membrane patches. Pflügers Arch 391:85-100.

Hawrot E, Patterson P (1979) Long-term culture of dissociated sympathetic neurons. Methods Enzymol 58:574-584.

Hille B (1992) Ionic channels of excitable membranes. Sunderland, MA: Sinauer.

Hirano T, Kidokoro Y, Ohmori H (1987) Acetylcholine dose-response relation and the effect of cesium ions in the rat adrenal chromaffin cell under voltage clamp. Pflügers Arch 408:401-407.

Hollmann M, Maron C, Heinemann S (1994) N-Glycosylation site tagging suggests a three transmembrane domain topology for the glutamate receptor GluR1. Neuron 13:1331-1343.

Hume RI, Dingeldine R, Heinemann SF (1991) Identification of a site in glutamate receptor subunits that controls calcium permeability. Science 253:1028-1031.

If une CK, Steinbach JH (1991) Voltage-dependent block by magnesium of neuronal nicotinic acetylcholine receptor channels in rat phaeochromocytoma cells. J Physiol (Lond) 443:683-701.

Ifune CK, Steinbach JH (1992) Inward rectification of acetylcholineelicited currents in rat phaeochromocytoma cells. J Physiol (Lond) 457:143-165.

Ifune CK, Steinbach JH (1993) Modulation of acetylcholine-elicited currents in clonal rat phaeochromocytoma (PC12) cells by internal polyphosphates. J Physiol (Lond) 463:431-447.

Imoto K, Busch C, Sakmann B, Mishina M, Konno T, Nakai J, Bujo H, Mori Y, Fukuda K, Numa S (1988) Rings of negatively charged amino acids determine the acetylcholine receptor channel conductance. Nature 335:645-648.

Johnson JW, Ascher P (1990) Voltage-dependent block by intracellular $\mathrm{Mg}^{++}$of $N$-methyl-D-aspartate-activated channels. Biophys J 57:1085-1090.

Kamboj SK, Swanson GT, Cull-Candy SG (1995) Intracellular spermine confers rectification on rat calcium-permeable AMPA and kainate receptors. J Physiol (Lond) 486:297-303.

Karlin A, Akabas MH (1995) Toward a structural basis for the function of nicotinic acetylcholine receptors and their cousins. Neuron 15:1231-1244.

Koh DS, Burnashev N, Jonas P (1995) Block of native Ca2+-permeable AMPA receptors in rat brain by intracellular polyamines generates double rectification. J Physiol (Lond) 486:305-312.

Mandelzys A, Pie B, Deneris ES, Cooper E (1994) The developmental increase in $\mathrm{ACh}$ current densities on rat sympathetic neurons correlates with changes in nicotinic ACh receptor $\alpha$-subunit gene expression and occurs independent of innervation. J Neurosci 14:2357-2364.
Mandelzys A, De Koninck P, Cooper E (1995) Agonist and toxin sensitivities of ACh-evoked currents on neurons expressing multiple nicotinic ACh receptor subunits. J Neurophysiol 74:1212-1221.

Marton LJ, Pegg AE (1995) Polyamines as targets for therapeutic intervention. Annu Rev Pharmacol Toxicol 35:55-91.

Mathie A, Colquhoun D, Cull-Candy SG (1990) Rectification of currents activated by nicotinic acetylcholine receptors in rat sympathetic ganglion neurones. J Physiol (Lond) 427:625-655.

Mathie A, Cull-Candy SG, Colquhoun D (1991) Conductance and kinetic properties of single nicotinic acetylcholine receptor channels in rat sympathetic neurones. J Physiol (Lond) 439:717-750.

McFarlane S, Cooper E (1992) Postnatal development of voltage-gated $\mathrm{K}$ currents on rat sympathetic neurons. J Neurophysiol 67:1291-1300.

McGehee DS, Role LW (1995) Physiological diversity of nicotinic acetylcholine receptors expressed by vertebrate neurons. Annu Rev Physiol 57:521-546.

McGehee DS, Role LW (1996) Presynaptic ionotropic receptors. Curr Opin Neurobiol 6:342-349.

McGehee DS, Heath MJS, Gelber S, Devay P, Role LW (1995) Nicotinic enhancement of fast excitatory synaptic transmission in CNS by presynaptic receptors. Science 269:1692-1696.

Neuhaus R, Cachelin AB (1990) Changes in the conductance of the neuronal nicotinic acetylcholine receptor channel induced by magnesium. Proc R Soc Lond B Biol Sci 241:78-84.

Nichols CG, Lopatin AN (1997) Inward rectifier potassium channels. Annu Rev Physiol 59:171-191.

Robichaud LJ, Boxer PA (1993) Polyamine modulation of excitatory amino acid responses in rat cortical wedge. Neuropharmacology 32:1025-1035.

Rock DM, MacDonald RL (1992) The polyamine spermine has multiple actions on $N$-methyl-D-aspartate receptor single channel currents in cultured cortical neurons. Mol Pharmacol 41:83-88.

Role LW, Berg DK (1996) Nicotinic receptors in the development and modulation of CNS synapses. Neuron 16:1077-1085.

Sands SB, Barish ME (1992) Neuronal nicotinic acetylcholine receptor currents in phaeochromocytoma (PC12) cells: dual mechanisms of rectification. J Physiol (Lond) 447:467-487.

Sargent PB (1993) The diversity of neuronal nicotinic acetylcholine receptors. Annu Rev Neurosci 16:403-443.

Steinlein OK, Mulley JC, Propping P, Wallace RH, Philips HA, Sutherland GR, Scheffer IE, Berkovic SF (1995) A missense mutation in the neuronal nicotinic acetylcholine receptor alpha 4 subunit is associated with autosomal dominant nocturnal frontal lobe epilepsy. Nat Genet 11:201-203.

Swaerd K, Nilsson BO, Hellstrand P (1997) Inhibition of polyamine synthesis influences contractility of intestinal smooth muscle in culture. Am J Physiol 223:77-84.

Traynelis SF, Hartley M, Heinemann SF (1995) Control of proton sensitivity of the NMDA receptor by RNA splicing and polyamines. Science 268:873-876.

Wada E, Wada K, Boulter J, Deneris E, Heinemann S, Patrick J, Swanson LW (1989) Distribution of $\alpha_{2}, \alpha_{3}, \alpha_{4}$, and $\beta_{2}$ neuronal nicotinic receptor subunit mRNA in the central nervous system: a hybridization histochemical study in the rat. J Comp Neurol 284:314-335.

Washburn MS, Dingledine R (1996) Block of $\alpha$-amino-3-hydroxy-5methyl-4-isoxazolepropionic acid (AMPA) receptors by polyamines and polyamine toxins. J Pharmacol Exp Ther 278:669-678.

Watanabe S, Kusama-Eguchi K, Kobayashi H, Igarashi K (1991) Estimation of polyamine binding to macromolecules at ATP in bovine lymphocytes and rat liver. J Biol Chem 266:20803-20809.

Weiland S, Witzermann V, Villarroel A, Propping P, Steinlein O (1996) An amino acid exchange in the second transmembrane segment of a neuronal nicotinic receptor causes partial epilepsy by altering its desensitization kinetics. FEBS Lett 398:91-96.

Williams K (1997) Modulation and block of ion channels: a new biology of polyamines. Cell Signal 9:1-13.

Williams K, Dawson VL, Romano C, Dichter MA, Molinoff B (1990) Characterization of polyamines having agonist, antagonist, and inverse agonist effects at the recognition site of the NMDA receptor. Neuron 5:199-208.

Woodhull AM (1973) Ionic blockage of sodium channels in nerve. J Gen Physiol 61:687-708. 